\title{
Thalamocortical and Intracortical Inputs Differentiate Layer-Specific Mouse Auditory Corticocollicular Neurons
}

\author{
(-Bernard J. Slater, ${ }^{1,3}$ Stacy K. Sons, ${ }^{2,3}$ Georgiy Yudintsev, ${ }^{1,3}$ Christopher M. Lee, ${ }^{2,3}$ and $\oplus^{-D a n i e l}$ A. Llano ${ }^{1,2,3}$ \\ ${ }^{1}$ Neuroscience Program and ${ }^{2}$ Department of Molecular and Integrative Physiology, University of Illinois Urbana-Champaign, Urbana, Illinois 61801, \\ and ${ }^{3}$ Beckman Institute for Advanced Science and Technology, Urbana, Illinois 61801
}

Long-range descending projections from the auditory cortex play key roles in shaping response properties in the inferior colliculus. The auditory corticocollicular projection is massive and heterogeneous, with axons emanating from cortical layers 5 and 6 , and plays a key role in directing plastic changes in the inferior colliculus. However, little is known about the cortical and thalamic networks within which corticocollicular neurons are embedded. Here, laser scanning photostimulation glutamate uncaging and photoactivation of channelrhodopsin- 2 were used to probe the local and long-range network differences between preidentified layer 5 and layer 6 auditory corticocollicular neurons from male and female mice in vitro. Layer 5 corticocollicular neurons were found to vertically integrate supragranular excitatory and inhibitory input to a substantially greater degree than their layer 6 counterparts. In addition, all layer 5 corticocollicular neurons received direct and large thalamic inputs from channelrhodopsin-2-labeled thalamocortical fibers, whereas such inputs were less common in layer 6 corticocollicular neurons. Finally, a new low-calcium/synaptic blockade approach to separate direct from indirect inputs using laser photostimulation was validated. These data demonstrate that layer 5 and 6 corticocollicular neurons receive distinct sets of cortical and thalamic inputs, supporting the hypothesis that they have divergent roles in modulating the inferior colliculus. Furthermore, the direct connection between the auditory thalamus and layer 5 corticocollicular neurons reveals a novel and rapid link connecting ascending and descending pathways.

Key words: auditory cortex; corticofugal; inferior colliculus; laser photostimulation; medial geniculate body; thalamus

\section{Significance Statement}

Descending projections from the cortex play a critical role in shaping the response properties of sensory neurons. The projection from the auditory cortex to the inferior colliculus is a massive, yet poorly understood, pathway emanating from two distinct cortical layers. Here we show, using a range of optical techniques, that mouse auditory corticocollicular neurons from different layers are embedded into different cortical and thalamic networks. Specifically, we observed that layer 5 corticocollicular neurons integrate information across cortical lamina and receive direct thalamic input. The latter connection provides a hyperdirect link between acoustic sensation and descending control, thus demonstrating a novel mechanism for rapid "online" modulation of sensory perception.

\section{Introduction}

As we navigate the environment, complex arrays of sounds must be selected, enhanced, or suppressed to guide behavior. Descend-

\footnotetext{
Received Nov. 13, 2017; revised 0ct. 10, 2018; accepted 0ct. 12, 2018.

Author contributions: G.Y. and C.M.L. edited the paper. B.J.S., G.Y., C.M.L., and D.A.L. designed research; B.J.S., S.K.S., G.Y., and C.M.L. performed research; B.J.S., G.Y., C.M.L., and D.A.L. analyzed data; B.J.S. and D.A.L. wrote the paper.

This work was supported by National Institute on Deafness and Other Communication Disorders F31DC013501 to B.J.S. and R01DC013073 to D.A.L. We thank Nhan Huynh for MATLAB coding assistance; Dr. Kush Paul for help with histological imaging; and University of Illinois Statistical Services for assistance with the analysis.

The authors declare no competing financial interests.

Correspondence should be addressed to Dr. Daniel A. Llano, Beckman Institute for Advanced Science and Technology, 405 N. Mathews Avenue, Urbana, IL 61801. E-mail: d-llano@illinois.edu.

B.J. Slater's present address: 213 Center for Neural Circuits and Behavior, University of California at San Diego, San Diego, CA 92161.
}

ing cortical projections are responsible for shaping auditory information, particularly in the inferior colliculus (IC), which is the main integration site for acoustic information before reaching the forebrain (for review, see Winer, 2006; Suga, 2008; Bajo and King, 2012; Stebbings et al., 2014). However, little is known about corticocollicular circuitry. Across multiple species, neurons from two cortical layers project to the IC: those from layer 5 and a smaller proportion from deep layer 6 (Games and Winer, 1988; Künzle, 1995; Coomes et al., 2005; Bajo et al., 2007; Schofield and Motts, 2009; Slater et al., 2013). A subset of the corticocollicular projection, primarily from layer 5 , targets contralateral IC (An-

https://doi.org/10.1523/JNEUROSC1.3352-17.2018

Copyright $\odot 2019$ the authors $\quad 0270-6474 / 19 / 390256-15 \$ 15.00 / 0$ 
dersen et al., 1980; Druga et al., 1997; Budinger et al., 2000a; Bajo et al., 2007; Schofield, 2009). Layer 5 corticocollicular neurons are large pyramidal neurons with thick apical dendrites that rhythmically burst when depolarized (Slater et al., 2013). Layer 5 corticocollicular neurons are morphologically and physiologically distinct from layer 5 neurons which project intracortically (Games and Winer, 1988; Llano and Sherman, 2009; Rock and Apicella, 2015). Layer 6 corticocollicular neurons, in contrast, are nonpyramidal, regular-spiking neurons with elongated somata and thin, but densely branching dendrites (Slater et al., 2013; Zurita et al., 2018). Therefore, similar to the corticothalamic system where layer 5 and layer 6 neurons have distinct roles in modulating the thalamus (Ojima, 1994; Reichova and Sherman, 2004; Llano and Sherman, 2009; Theyel et al., 2010), there are two major types of neurons comprising the corticocollicular projection. These two populations may be responsible for the diverse collicular responses observed after manipulations of this pathway.

To better understand the mechanisms by which the auditory cortex (AC) modulates the IC, it is important to understand how corticocollicular neurons are integrated into local cortical and thalamocortical networks. Previous studies of layer 5 cortical neurons have shown that these neurons receive local excitatory and inhibitory cortical inputs from near the soma as well as from supragranular layers (Schubert et al., 2001, 2006; Thomson et al., 2002; Llano and Sherman, 2009; Hooks et al., 2013; Zarrinpar and Callaway, 2016). This distribution of inputs is in contrast to the inputs to layer 6 corticothalamic neurons, which receive the majority of their excitatory and inhibitory input from layer 6 (Llano and Sherman, 2009). With respect to thalamic input, while the canonical view is that the thalamus provides input to layer 4, thalamocortical fibers also have been shown to contact other layers, including dendrites of layer 5 and layer 6 neurons (Huang and Winer, 2000; Zhao et al., 2009; Yang et al., 2014; Ji et al., 2016). In addition, direct thalamic input to the infragranular cortical layers has been shown to result in suprathreshold responses, particularly in layer 5 intrinsically bursting neurons (Constantinople and Bruno, 2013). These layer 5 neurons send their axonal projections to subcortical nuclei, providing a rapid route to connect the ascending and descending projections. However, the presence of a direct thalamic input to auditory corticocollicular neurons has not yet been investigated. Such a pathway could be a substrate for nearly "online" modulation of ascending signals, where some of the input is relayed to lower centers and is minimally processed in the cortex before transmission.

Here, we examined the local cortical and thalamocortical networks within which layer 5 and layer 6 corticocollicular neurons are embedded by using a range of optical stimulation approaches. The results of this work demonstrate a previously unknown degree of synaptic heterogeneity influencing the auditory corticocollicular system, and may account for the myriad effects of cortical stimulation on the auditory midbrain (Mitani et al., 1983; Zhang et al., 1997; Gao and Suga, 2000; Ma and Suga, 2001; Yan and Ehret, 2001; Nakamoto et al., 2008, 2010; Bajo et al., 2010; Robinson et al., 2016).

\section{Materials and Methods}

Animals. All procedures were approved by the Institutional Animal Care and Use Committee at the University of Illinois. All animals were housed in animal care facilities approved by the American Association for Assessment and Accreditation of Laboratory Animal Care. BALB/c mice were bred in-house. Young adult mice of this strain have previously been established as having normal hearing (Zheng et al., 1999).
Animal preparation for slice experiments. For injections of tracers, mice of either sex at 1-2 months of age were anesthetized with an intraperitoneal injection of ketamine hydrochloride $(100 \mathrm{mg} / \mathrm{kg})$ and xylazine $(3$ $\mathrm{mg} / \mathrm{kg}$ ) and then carefully placed in a stereotaxic apparatus to avoid damage to peripheral auditory structures. Lidocaine (1\%) was injected subcutaneously at incision sites before surgery as a supplement to anesthesia. Injection targets in the IC (see Fig. $1 A$ ) and medial geniculate body (MGB, see Fig. 1D) were localized using stereotactic coordinates (for IC injections, $0.75 \mathrm{~mm}$ caudal from $\lambda, 0.75 \mathrm{~mm}$ lateral to midline, and $0.5-1$ $\mathrm{mm}$ depth from the dorsal surface; for MGB injections, $3.18 \mathrm{~mm}$ caudal from bregma, $2.0 \mathrm{~mm}$ lateral to the midline, and $3.2 \mathrm{~mm}$ from the dorsal surface). No attempt was made to isolate injections to individual subdivisions of the target structures. For all animals, micropipettes (tip diameter $10 \mu \mathrm{m}$ ) were filled with $250-300 \mathrm{nl}$ of latex microspheres (Lumafluor Retrobeads) and injected into the IC over 5-10 min using a Nanoliter 2000 injection system (World Precision Instruments). To allow for retrograde transport of the beads from the IC (see Fig. 1B) to layer 5 and layer 6 corticocollicular neurons in the AC (see Fig. 1C), animals were euthanized $>3 \mathrm{~d}$ after the injection. For animals receiving MGB injections, at least 2 weeks before IC injections, animals were injected with 250-300 $\mathrm{nl}$ of the adeno-associated virus 2 (AAV2) construct of AAV-CaMKIIa-hChR2(H134R)-mCherry (University of North Carolina Vector Core, Chapel Hill, NC) virus at $4.55 \times 10^{12}$ viral genomes $/ \mathrm{ml}$ diluted in $1 \%$ Polybrene in PBS into the MGB (see Fig. $1 E$ ), resulting in robust expression in thalamocortical afferents (see Fig. $1 F$ ). Although the retrogradely labeled neurons (labeled with red retrobeads) and thalamocortical afferents (labeled with mCherry) fluoresce using similar wavelengths, they are easily distinguishable under high magnification. In addition, AAV2 shows virtually only anterograde expression (Harris et al., 2012), ensuring that none of the recorded neurons were retrogradely filled corticothalamic neurons.

Hearing threshold testing. For auditory brainstem responses, BALB/C mice of either sex at $\sim 2$ months of age were tested using white noise and pure tones at frequencies of $8,16,32$, and $48 \mathrm{kHz}$. Animals were anesthetized with intraperitoneal ketamine hydrochloride $(100 \mathrm{mg} / \mathrm{kg})$ and $\mathrm{xy}-$ lazine $(3 \mathrm{mg} / \mathrm{kg})$ before the insertion of three subdermal electrodes: one at the vertex, one behind the left ear, and a reference electrode placed at the base of the tail. Stimuli were presented using a System 3, ES1 free field speaker (Tucker-Davis Technologies), with waveforms generated by SigGen software. The output of the speaker (Tucker-Davis Technologies) was calibrated at all the relevant frequencies, using a Type 4135 microphone and a measuring amplifier (model 2610; Brüel and Kjær ). Each frequency was presented for $5 \mathrm{~ms}$ ( $3 \mathrm{~ms}$ flat with $1 \mathrm{~ms}$ for both rise and fall times), at a rate of $7 \mathrm{~Hz}$, with a $45 \mathrm{~ms}$ analysis window. Raw potentials were obtained with a RA4LI headstage, RA16PA preamp, and RA16 Medusa Base station (Tucker-Davis Technologies), and filtered between 100 and $5000 \mathrm{~Hz}$. Waveforms were averaged 500 times. Significant deflections, assessed via visual inspection, within $10 \mathrm{~ms}$ after the onset of the stimulus were deemed a response.

Thalamocortical slices. To obtain brain slices, each animal was deeply anesthetized by intraperitoneal injection of ketamine hydrochloride (100 $\mathrm{mg} / \mathrm{kg}$ ) and xylazine $(3 \mathrm{mg} / \mathrm{kg}$ ), then transcardially perfused with an ice-cold high-sucrose cutting solution (in $\mathrm{mm}$ as follows: 206 sucrose, 10.0 $\mathrm{MgCl}_{2}, 11.0$ glucose, $1.25 \mathrm{NaH}_{2} \mathrm{PO}_{4}, 26 \mathrm{NaHCO}_{3}, 0.5 \mathrm{CaCl}_{2}, 2.5$ $\mathrm{KCl}, \mathrm{pH}$ 7.4) following which the brain was quickly removed. A modified version of the auditory thalamocortical slice (Cruikshank et al., 2002) was used for these experiments. As described previously (Llano et al., 2014; Slater et al., 2015), the IC was retained in this slice to allow visualization of the colliculus injection site (see Fig. 1B). The $300 \mu \mathrm{m}$ slices were cut using a vibrating tissue slicer (Leica Microsystems VT1000s). Although thicker slices are viable (Llano et al., 2014) and may reveal greater connectivity, $300 \mu \mathrm{m}$ was chosen to enhance visibility in slices. Slices were then transferred to a holding chamber containing oxygenated incubation aCSF (in mM as follows: $126 \mathrm{NaCl}, 3.0 \mathrm{MgCl}_{2}, 10.0$ glucose, $1.25 \mathrm{NaH}_{2} \mathrm{PO}_{4}, 26 \mathrm{NaHCO}_{3}, 1.0 \mathrm{CaCl}_{2}, 2.5 \mathrm{KCl}, \mathrm{pH} 7.4$ ) at $32^{\circ} \mathrm{C}$ for $1 \mathrm{~h}$ before recording. Given this orientation of slice, which is angled at $\sim 15$ degrees from the horizontal plane, the terms "dorsal" and "lateral" are somewhat ambiguous. For consistency, for the current report, "dorsal" refers to regions of the slice closer to the pial surface over the AC. 
Electrophysiological recording. Whole-cell and cell-attached recordings were obtained using a visualized slice electrophysiology setup, outfitted with infrared-differential interference contrast optics and fluorescence, and performed at room temperature. Room temperature was used to increase slice viability, although it should be noted that certain dynamic properties (e.g., bursting) are likely to be altered at this temperature (Markram et al., 1995; Slater et al., 2013). Cell-attached recordings are derived from different cells than those used for the laser mapping experiments. The Multiclamp 700B amplifier (Molecular Devices) and pClamp software (Molecular Devices) were used for data acquisition, sampled at $20 \mathrm{kHz}$. Recordings were done in the primary AC, as defined by horizontal atlas images in Franklin and Paxinos (2007). Borosilicate glass capillary tubes were pulled to obtain recording pipettes. These pipettes were then filled with recording solution (for cell-attached recordings, in mM as follows: $117 \mathrm{~K}$-gluconate, $13 \mathrm{KCl}, 1.0 \mathrm{MgCl}_{2}, 0.07 \mathrm{CaCl}_{2}$, 0.1 EGTA, 10.0 HEPES, 2.0 Na-ATP, 0.4 Na-GTP, 0.01 Alexa-568 or -488 hydrazide, and $0.5 \%$ biocytin, $\mathrm{pH} 7.3$; and intracellular recordings, in $\mathrm{mm}$ as follows: 117.0 $\mathrm{CsOH}, 117.0$ gluconic acid, $11.0 \mathrm{CsCl}, 1.0$ $\mathrm{MgCl}_{2}{ }^{*} 6 \mathrm{H}_{2} \mathrm{O}, 0.07 \mathrm{CaCl}_{2}, 11.0$ EGTA, 10.0 HEPES). Laser stimulation was done with slices bathed in aCSF (in mM as follows: $126 \mathrm{NaCl}, 2.0$ $\mathrm{MgCl}_{2}, 10.0$ glucose, $1.25 \mathrm{NaH}_{2} \mathrm{PO}_{4}, 26 \mathrm{NaHCO}_{3}, 2.0 \mathrm{CaCl}_{2}, 2.5 \mathrm{KCl}$, and $0.05 \mathrm{APV}, \mathrm{pH} 7.4$ with $150 \mu \mathrm{M}$ MNI-glutamate (Tocris Bioscience). APV (Tocris Bioscience), a selective competitive inhibitor of the NMDA receptor, was used to limit recurrent excitation, therefore limiting excitation to monosynaptically driven currents (Shepherd, 2012).

Photostimulation. Cell-attached recordings of laser-driven spikes were done after an observed increase in series resistance to $\sim 1$ gigaOhm. A UV laser (355 nm wavelength, frequency-tripled $\mathrm{Nd}: \mathrm{YVO} 4,100 \mathrm{kHz}$ pulse repetition rate; DPSS Lasers) was used for these experiments. Laser power was adjusted using an acousto-optical modulator (Gooch and Housego). The laser is directed into the side port of an Olympus microscope (BX51WI) using a series of UV-enhanced aluminum mirrors (Thorlabs) and a pair of mirror galvanometers (Cambridge Technology) and is reflected off of a 400-nm-long pass dichroic mirror to allow for laser stimulation as well as visualization of fluorescently labeled neurons. The laser beam is focused onto the brain slice with a low-magnification objective $(4 \times 0.13 \mathrm{NA}$ infinity corrected Plan, Olympus $)$ and used to uncage glutamate at $15.8 \mathrm{~mW}$, measured with a thermal sensor power meter (PM160T, Thorlabs). One ms pulses controlled by the acoustooptical modulator were used to obtain a series of traces corresponding to glutamatergic responses at each point. For cell-attached recordings used to classify the excitation profile of auditory cortical neurons, a $10 \times 10$ grid with adjacent rows and columns spaced $10 \mu \mathrm{m}$ apart was used. Glutamate uncaging was done at successive non-neighbor points to prevent depletion of the caged glutamate, glutamate toxicity, and habituation at the probed synapses. Spikes were visually identified and assigned to points in the $10 \times 10$ maps; four runs were used to record the neuronal activations for each cortical layer. Spikes were considered to be reliably driven by laser input if they occurred within $5 \mathrm{~ms}$ after the laser pulse and in at least half of the repeated $10 \times 10$ maps at a given point.

For corticocollicular mapping, individual labeled corticocollicular neurons were identified using the presence of fluorescent latex beads (Lumafluor Retrobeads) identified by fluorescence optics (Olympus filter set U-MWG2, excitation $510-550 \mathrm{~nm}$, dichroic $570 \mathrm{~nm}$, and emission 590-nm-long pass filter) using a $200 \mathrm{~W}$ metal arc lamp (Prior). To obtain input maps, once a cell was successfully patched, MNI-glutamate was introduced into the circulating aCSF at $150 \mu \mathrm{M}$. A $30 \times 30$ grid of points with $35 \mu \mathrm{m}$ spacing between adjacent rows and columns was then placed over the cortex surrounding the corticocollicular cell using the Prairie View software (Bruker). Each grid of laser stimulation points was run at least three times, first held at $+10 \mathrm{mV}$ to record IPSCs, next while the neuron was held at $-60 \mathrm{mV}$ to measure excitatory currents, and then the bathing solution was switched to a low-calcium aCSF (in mM as follows: $126 \mathrm{NaCl}, 4.0 \mathrm{MgCl}_{2}, 10.0$ glucose, $1.25 \mathrm{NaH}_{2} \mathrm{PO}_{4}, 26 \mathrm{NaHCO}_{3}, 0.01$ $\mathrm{CaCl}_{2}, 2.5 \mathrm{KCl}, 0.05 \mathrm{APV}, \mathrm{pH} 7.4$ ), which limits synaptic transmission, while the neuron was again held at $-60 \mathrm{mV}$ to record direct glutamate stimulation of the recorded neuron. QX-314 (Tocris Bioscience) $50 \mu \mathrm{M}$ was added to the intracellular solution above to eliminate voltagedependent sodium currents. The same laser stimulation parameters were used to stimulate labeled channelrhodopsin-2 (ChR-2)-expressing fibers and terminals. ChR-2 excitation is typically performed using blue light; however, the dichroic mirror necessary for use of a $488 \mathrm{~nm}$ laser does not allow for visualization of the red fluorescent latex beads used to visualize back-labeled corticocollicular neurons. Therefore, a UV laser was used, which we and others (Petrof et al., 2015) have found to robustly activate ChR-2, given the extended short-wavelength tail of the ChR-2 absorption spectrum (Zhang et al., 2007).

Laser map analysis. Electrophysiological analyses were performed with Clampfit followed by further analysis in custom-written MATLAB software (The MathWorks). For each pixel, a prestimulation baseline period of $100 \mathrm{~ms}$ was compared with a poststimulation analysis period of 150 $\mathrm{ms}$. Statistical maps were created by computing the $F$ statistic (variance of the poststimulation analysis period divided by the variance of the baseline period) for each stimulation site, and maps were thresholded based on a ratio of 2.0. $F$ statistics were used to account for prestimulation variability and spontaneous activity, and are commonly used in the brain imaging literature (Howseman et al., 1997; Friston, 1998; Bowman, 2014). For quantitative comparison of inward or outward currents, currents were integrated over $150 \mathrm{~ms}$ to compute the total inward or outward charge transfer. To minimize the impact of spontaneous inward or outward currents, sites were only counted if two or more adjacent sites produced inward or outward currents in the recorded neuron, as previously described (Sturm et al., 2017). Identical $30 \times 30$ stimulation grids were used for each neuron. Therefore, to combine data across neurons, maps were aligned to the recording site. A $4 \times 4$ Gaussian kernel with a $\mathrm{SD}$ of 0.5 pixels $(17.5 \mu \mathrm{m})$ was convolved across each map to minimize the impact of subtle misalignment, as is ubiquitously done in the imaging literature (Worsley et al., 2002; Penny et al., 2011; Gramfort et al., 2015), and maps were averaged, pixel by pixel, across neurons. To compare the spread of excitatory or inhibitory inputs to recorded cells, a 1D Gaussian was fit to the current inputs around recorded cells, and the SD was computed. FWHM was computed at $2.355 \times \mathrm{SD}$ (Assimakopoulos et al., 1986). For the generation of average maps (see, e.g., Fig. $5 A, B$ ), input maps were shifted and aligned by the site of the recording electrode, and all stimulus sites were classified by their distance to the recording electrode. For layer-based analyses (see, e.g., Fig. $5 D, E$ ), layers were determined on a per-slice basis using high-contrast images of the cortex (see, e.g., Fig. 5C) to identify layers. For display only, heatmaps were smoothed using bilinear interpolation in MATLAB.

Neuroanatomical studies: cell counts. Ten BALB/c mice of either sex ranging in age from 1.5 to 3 months of age were anesthetized with ketamine hydrochloride $(100 \mathrm{mg} / \mathrm{kg})$ and xylazine $(3 \mathrm{mg} / \mathrm{kg})$ intraperitoneally and placed in a stereotaxic apparatus. For retrograde tracing of the corticocollicular projection, Fluoro-Gold (Fluorochrome) was first dissolved (1\%) in acetate buffer at $\mathrm{pH} 3.4$, and then a small piece of gel foam was soaked in this solution containing Fluoro-Gold and placed into the left IC. In some cases, the tracer was delivered through a $20 \mu \mathrm{m}$ brokentip glass electrode for $10-15 \mathrm{~min}$ at $10 \mu \mathrm{A}$ positive current, with $7 \mathrm{~s}$ on and $7 \mathrm{~s}$ off duty cycle (each of these methods generated similar results). Animals were allowed to survive for 5-7 d after injection, and after were deeply anesthetized with ketamine and xylazine delivered intraperitoneally, followed by transcardial perfusion with $4 \%$ PFA in PBS at pH 7.4. Two fiducial markers were placed in brain tissue along the rostrocaudal axis using a 27-gauge needle dipped into water-insoluble black India ink: one through the dorsal portion of the hippocampus and the other through the ventral portion of the hippocampus. The third fiducial marker was the rhinal fissure. These markers were used to align the sections to enable post hoc 3D reconstruction. Frozen $50 \mu \mathrm{m}$ coronal sections were cut using a sliding microtome. Sections containing primary regions of AC were confirmed with neurofilament protein SMI-32 (Budinger et al., 2000b) and were serially photographed using an Olympus fluorescence microscope using a $5 \times 0.15 \mathrm{NA}$ objective. $3 \mathrm{D}$ images of the primary regions of the left $\mathrm{AC}$ were reconstructed using Neurolucida (MBF Bioscience). Layer 5 and 6 corticocollicular neurons were manually selected in Neurolucida and marked with one of two different symbols designated for each layer. Cell counts obtained in Neurolucida were adjusted separately as per the Abercrombie method (Abercrombie, 1946). Total percentages of layer 5 and 6 corticocollicular neurons were 
first calculated for each animal $(n=10)$, and then the means were calculated for all animals.

Neuroanatomical studies: triple virus injections. To identify thalamocortical terminals on layer 5 corticocollicular neurons, BALB/c mice of either sex at 2-3 months of age were anesthetized with ketamine hydrochloride $(100 \mathrm{mg} / \mathrm{kg})$ and xylazine $(3 \mathrm{mg} / \mathrm{kg})$ intraperitoneally and placed in a stereotaxic apparatus. First, to induce Cre-recombinase expression (to allow dendritic labeling) in corticocollicular neurons, $400 \mathrm{nl}$ of the retrograde virus AAV-pkg-Cre (Addgene catalog \#24593) at a concentration of $7.0 \times 10^{12}$ viral genomes $/ \mathrm{ml}$ diluted in PBS was injected into the IC, without regard to subdivision. Second, to label thalamocortical afferents, an injection of $400 \mathrm{nl}$ of AAV2-CaMKIIa-hChR2 (H134R)-mCherry (University of North Carolina Vector Core, Chapel Hill, NC) virus at $4.55 \times 10^{12}$ viral genomes $/ \mathrm{ml}$ was made into the ipsilateral MGB. A third injection was then made into the ipsilateral primary AC using a Cre-dependent fluorophore to visualize the cells expressing Cre-recombinase. For this, 150-200 nl of AAV9-CAG-FlexeGFP-WPRE-bGH (Penn Vector Core, Philadelphia) at a concentration of $1.0 \times 10^{13}$ viral genomes $/ \mathrm{ml}$ was injected. Animals were then euthanized 5 weeks later, perfused for histology, and $50 \mu \mathrm{m}$ sections were cut at the same orientation as those for in vitro slice physiology. After drying and coverslipping, sections were imaged and visualized using a Leica Microsystems SP8 laser scanning confocal microscope. Terminals were identified as being on layer 5 corticocollicular neurons if they were directly visualized on back-labeled layer 5 neuronal somata or adjacent dendrites or more distally on back-labeled thick apical dendrites, which are not seen on layer 6 corticocollicular neurons (Slater et al., 2013).

Statistical analysis. All statistical tests were run using MATLAB or SPSS (IBM). Shapiro-Wilk testing for normality was performed on all datasets; and in all cases, data were found to be non-normal. Therefore, nonparametric testing was done. Specific tests (Mann-Whitney $U$ test, Spearman's correlation, $\chi^{2}$, and Kolmogorov-Smirnov two-sample test) were applied as described in Results. To account for multiple comparisons, a post hoc Holm-Bonferroni approach (Holm, 1979) was used. Error bars indicate SD.

\section{Results}

\section{Mouse numbers: hearing thresholds and injections}

Hearing thresholds of $12 \mathrm{BALB} / \mathrm{c}$ mice (mean \pm SD age $=54.8 \pm$ $11.4 \mathrm{~d}$ ) were tested. These mice were found to have noise and best tone thresholds of $33.4 \pm 4.9$ and $30.8 \pm 8.1 \mathrm{~dB}$ SPL, respectively, similar to what has been described for $\mathrm{BALB} / \mathrm{c}$ mice previously in the comprehensive study by Zheng et al. (1999), who had characterized BALB/c mice as having normal hearing. Ten BALB/c mice were injected with Fluoro-Gold into the IC to quantify the distributions of layer 5 and layer 6 corticocollicular neurons. Seven BALB/c mice were injected with red retrobeads into the IC to back-label layer 5 and layer 6 corticocollicular neurons for physiological recordings (Fig. $1 A-C$ ). An additional 5 mice had a combination of red retrobeads injected into the IC and AAVCaMKIIa-hChR2(H134R)-mCherry into the auditory thalamus ( 5 animals, Fig. $1 D-F$ ) to permit thalamic stimulation of identified corticocollicular neurons. Two mice were used for triple virus injections. For a summary of experiments and animals used, please see Table 1 .

\section{Anatomical characterization of layer-specific distribution of corticocollicular projections}

The distributions of corticocollicular neurons after bulk labeling of the IC with Fluoro-Gold and delineation of the primary AC using immunostaining for SMI-32 were quantified. Across 10 animals, it was found that 25\% (SD 4\%) of the back-labeled cells were in layer 6 (Fig. $1 G-I$ ) and the remaining 75\% (SD 4\%) were in layer 5 . These data suggest that layer 6 corticocollicular neurons comprise a substantial minority of the auditory corticocollicular pathway in mice.

\section{Cell-attached recordings}

To determine the functional spatial resolution of the laser stimulation parameters described in Materials and Methods, excitation profiles in cortical neurons were measured using cellattached recordings from unlabeled neurons in layers 2-6 (layer 6: $n=3$; layer $5: n=4$; layer $4: n=5$; layer $2 / 3: n=4)$, similar to previous studies (Zarrinpar and Callaway, 2006; Sturm et al., 2014; Kratz and Manis, 2015). A $10 \times 10$ spot grid, with $10 \mu \mathrm{m}$ spacing between adjacent rows and columns, was centered over the recorded cell to direct UV laser photostimulation (Fig. 2A). Four mapping trials were run to measure the spiking reliability of auditory cortical neurons to a given stimulation point. Stimulation locations in which the cell responded with a spike (inset Fig. $2 A$ ) in half or more trials were considered reliably driven and therefore used for analysis. All neurons sampled $(n=16)$ had relatively small excitation profiles (example shown in Fig. $2 \mathrm{~B}, \mathrm{C}$ ). Reliable photostimulation-driven spiking (i.e., seen on at least $50 \%$ of the trials) was observed with a mean \pm SD width of $20.0 \pm$ $7.7 \mu \mathrm{m}$ in the rostrocaudal direction and $30.9 \pm 14.6 \mu \mathrm{m}$ in the dorsoventral direction (Fig. 2D). This information was used to design later mapping experiments using a larger stimulus grid, for which $35 \mu \mathrm{m}$ interstimulus spacing was used.

\section{Mapping of inputs to identified corticocollicular neurons}

To test the hypothesis that layer 5 and layer 6 corticocollicular neurons receive different sets of local inputs, sequential recording of paired preidentified layer 5 and layer 6 corticocollicular neurons within $150 \mu \mathrm{m}$ rostrocaudal distance of each other was done ( $n=8$ neurons in each layer). Laser photostimulation across 900 stimulus sites $(30 \times 30$ grid $)$ was used to uncage glutamate to measure local cortical excitatory inputs (by holding the cell at $-60 \mathrm{mV}$ ) and inhibitory inputs (by holding the cell at $10 \mathrm{mV}$ ).

Traditionally, a time window, typically in the range of 7-12 $\mathrm{ms}$, is used to separate inward currents caused by direct activation of postsynaptic glutamate receptors on the recorded cell from synaptic responses induced by stimulation of neurons providing synaptic input to the recorded neurons (Jin et al., 2006; Hooks et al., 2013; Sturm et al., 2014; Meng et al., 2015). Using this time window-based approach, sites with latencies less than the predefined time window are deemed "direct" and sites with latencies beyond this window are deemed "synaptic." Therefore, stimulation sites near the recorded cell that produce a mixture of direct and synaptic inward currents are removed from the analysis, potentially biasing the inward current maps to only reflect more distant inputs. To remove this bias, similar to previous work (Staiger et al., 1999; Llano and Sherman, 2009), we generated repeat maps created in a synaptic blockade medium with low calcium $(0.01 \mathrm{~mm})$ and high magnesium $(4.0 \mathrm{~mm})$ and subtracted the synaptic blockade map (which should reflect only direct currents) from the total inward current map. The resulting subtraction map should only reflect synaptic currents. An example for an identified layer 6 corticocollicular cell is shown in Figure $3 A-D$, showing the total inward current map (Fig. $3 A$ ), the map obtained with low-calcium aCSF (Fig. $3 B$ ), and the map generated by subtracting the low-calcium map from the normal aCSF map (Fig. 3C). As shown in Figure 3C, most of the synaptic input to this cell is from nearby regions in layer 6 . An example of a site that would have been eliminated using the traditional time window method, but retained using the low-calcium method, is shown in Figure $3 D$ (corresponding to Fig. $3 A-C$, asterisk). After glutamate stimulation, this site produced two inward currents: an early inward current that was retained after synaptic blockade, 


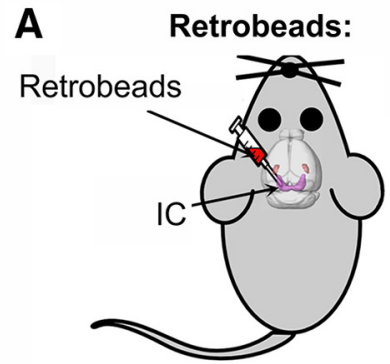

3 days before slicing

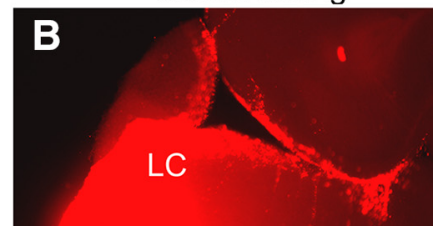

DC CNIC

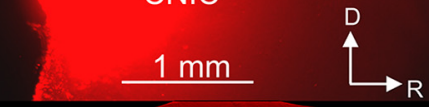

C

AC

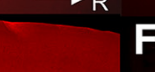

\section{E}

D Channelrhodopsin:

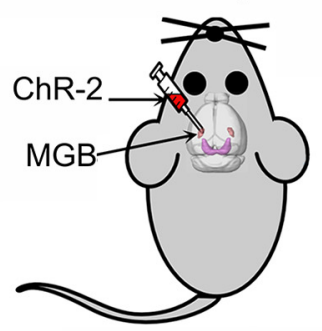

2-3 weeks before slicing

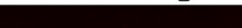

MGB

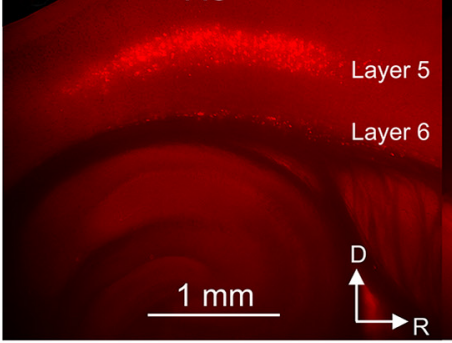

F
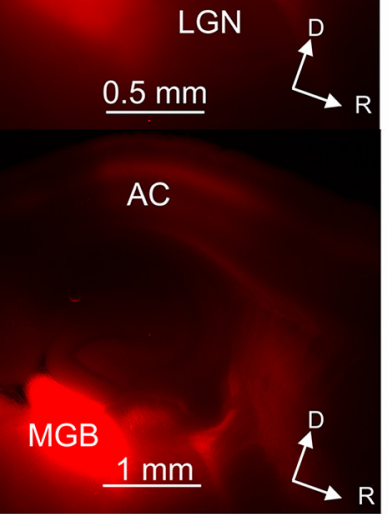

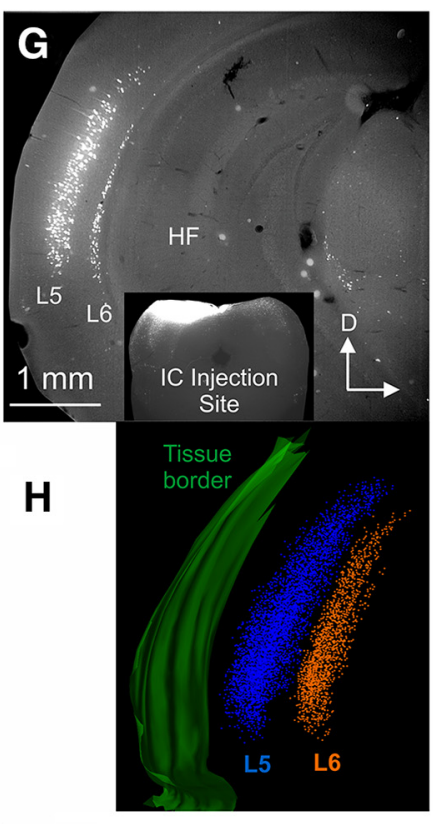

I 80

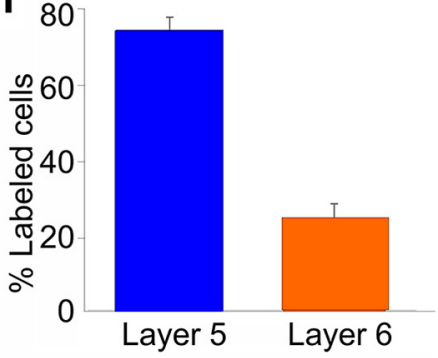

Figure 1. Overview of injections and proportion of corticocollicular projection from each layer. $A$, Latex beads were injected into the IC at least $3 \mathrm{~d}$ before brain slicing. $\boldsymbol{B}, \mathrm{IC}$ injection site covering portions of the lateral cortex (LC), dorsal cortex (DC), and central nucleus of the IC (CNIC). C, Layer 5 and layer 6 auditory corticocollicular neurons are filled with latex beads after retrograde transport. D, ChR-2 AAV was injected into the MGB at 2-3 weeks before preparation of brain slices. E, Injection site of AAV-CaMKIla-hChR2(H134R)-mCherry showing the labeled MGB region and radiating labeled axons. $\boldsymbol{F}$, After 2-3 weeks, ChR-2 is robustly expressed in the MGB with afferents projecting to the AC. G, Low-power imaging showing retrogradely labeled corticocollicular neurons in the AC after Fluoro-Gold injection into the IC. Inset, Injection site. $\boldsymbol{H}$, Neurolucida image showing the cumulative representation of labeled cells in all sections containing the primary AC of the brain shown in $\mathbf{G}$. The only features marked on each Neurolucida image were the tissue border (green), layer 5 corticocollicular cells (blue), and layer 6 corticocollicular cells (orange). $I$, Mean percentages of layer 5 corticocollicular cells versus layer 6 corticocollicular cells across $n=10$ animals. D, Dorsal; HF, hippocampal formation; L5, layer 5; L6, layer 6; LGN, lateral geniculate nucleus; R, rostral.

Table 1. Summary of all animals used in this study ${ }^{a}$

\begin{tabular}{lll}
\hline Experiment & No. of mice & No. of recorded neurons \\
\hline ABR recordings & 12 & NA \\
Retrograde tracing for quantification of layer 5 versus layer 6 distribution & 10 & NA \\
Laser uncaging of glutamate for mapping of inputs & 7 & 8 cells per layer \\
Double injection of retrobeads into IC and AAV-ChR2 into MGB for stimulation of thalamocortical terminals & 5 & Without TTX:5 cells per layer \\
Triple injection of retrograde AAV virus into IC, AAV-mCherry into MGB, and Cre-dependent AAV in AC & 2 & With TTX: 11 cells in layer 5 and 13 cells in layer 6 \\
\hline
\end{tabular}

${ }^{a}$ All animals are $B A L B / C, 2-3$ months old, both sexes.

and a later current, starting $\sim 9 \mathrm{~ms}$ after the direct current, which was presumably synaptic in nature. These data suggest that the low-calcium method retains activation sites that would have been eliminated using the time window method.

Although the gold standard for eliminating synaptic inputs is the use of TTX (Callaway and Katz, 1993; Sturm et al., 2017), the long duration of action of TTX makes it difficult to record from more than one cell in a slice. To determine whether the map obtained in the presence of TTX (dissolved in otherwise normal aCSF) is similar to the map obtained under low-calcium conditions, a layer 5 neuron was recorded under both conditions and shown in Figure $3 E-G$. Figure $3 E$ shows the inward current map of the cell under low-calcium conditions, whereas Figure $3 F$ shows the same cell in the presence of TTX. As shown, the maps are qualitatively similar. Correlation of the inward currents generated under the two conditions is shown in Figure 3G. As shown, the inward currents are highly correlated (Spearman's $\rho=0.954$, $p<0.001)$. These data suggest that a low-calcium solution mimics data obtained under TTX. Therefore, for analysis of local input maps of each neuron described below, three maps were obtained: a map obtained in routine aCSF, with the cell held at $-60 \mathrm{mV}$; a map obtained in low-calcium aCSF, with the cell held at $-60 \mathrm{mV}$; and a map obtained in routine aCSF, with the cell held at $+10 \mathrm{mV}$ to record inhibitory inputs. 

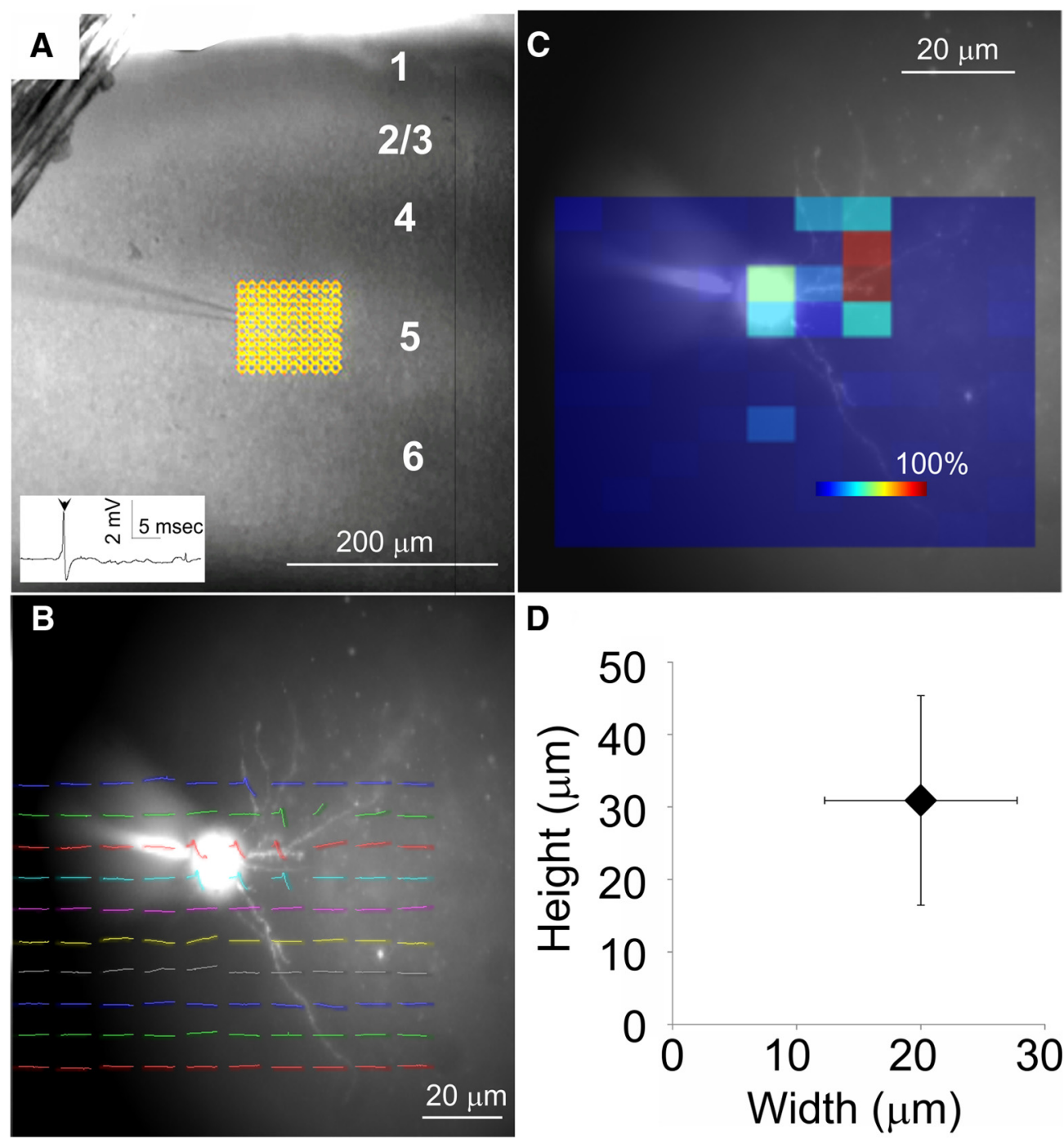

D

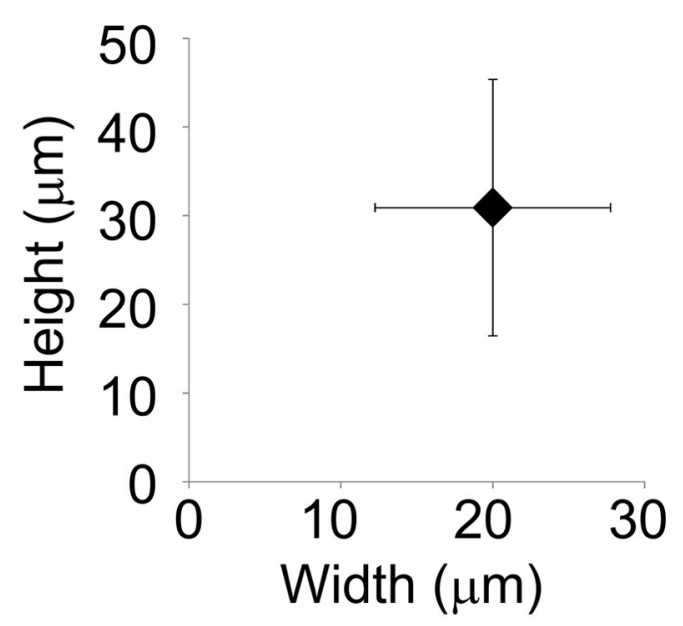

Figure 2. Cell-attached recordings. $A$, Unlabeled neurons across layers 2- 6 of the $A C$ were recorded from using a cell-attached approach. A tight $10 \times 10$ grid of points with $10 \mu \mathrm{m}$ spacing was centered over the cell and glutamate was uncaged in successive non-neighboring points. Inset, Spiking activity was determined visually (arrowhead). $\boldsymbol{B}$, After recording, the cell membrane seal is broken to permit entry of fluorescent Alexa hydrazide to view cell morphology. Shown here are the unshuffled traces, plotted over the filled dendritic processes of the cell. $\boldsymbol{C}$, Heatmap indicating the likelihood of eliciting a spike at each site around the neuron. Colorbar indicates percentage of stimuli eliciting a spike. $\boldsymbol{D}$, Average width versus average height of the excitation profiles ( $n=11$ cells) with SD error bars.

Using the approach described above, we recorded from eight sequentially recorded pairs of neurons: one identified layer 5 corticocollicular cell and one identified layer 6 corticocollicular cell. An example of such a pair of recordings is shown in Figure 4. As shown in Figure $4 A, B$, the layer 5 corticocollicular neuron receives prominent synaptic input from a region near the cell body in layer 5 as well as from a region approximately vertically aligned with the cell body in layer $2 / 3$. The excitation and inhibition appear to be approximately spatially matched. Synaptic traces from representative laser stimulation sites show mostly shortlatency, multipeaked induced currents. The extension of stimulation sites into layer 1 is likely related to dendritic activation of layer $2 / 3$ cells. The stimulation intensity was chosen for the average neuron recorded in cell-attached mode such that some neurons may show dendritic activation. Overall, there was weak input from layer 1 to layer 5 neurons (see below).

In contrast, a layer 6 corticocollicular cell immediately ventral to the layer 5 corticocollicular cell described above has a much more spatially restricted synaptic input area. As shown in Figure
$4 C, D$, this cell primarily receives input from layer 6 . This restricted degree of input to this layer 6 cell is unlikely to be related to poor slice connectivity or poor slice health because the layer 5 cell from the same slice retained excellent connectivity, and the synaptic currents recorded in the layer 6 corticocollicular cell were as robust as those recorded from the layer 5 corticocollicular cell from the same slice (see synaptic traces adjacent to each map).

\section{Composite laser stimulation maps}

Maps across all layer 5 corticocollicular neurons and layer 6 corticocollicular neurons were aligned and averaged to produce composite maps for layer 5 corticocollicular cell synaptic inward currents (Fig. $5 A 1$ ), layer 5 corticocollicular cell outward currents (Fig. 5A2), layer 6 corticocollicular cell synaptic inward currents (Fig. 5A3), and layer 6 corticocollicular cell outward currents (Fig. 5A4). Currents were collapsed across the vertical or the horizontal dimension to produce plots of synaptic input across the ventral-dorsal dimension (Fig. 5B, top) or across the rostrocaudal dimension (Fig. 5B, bottom). 

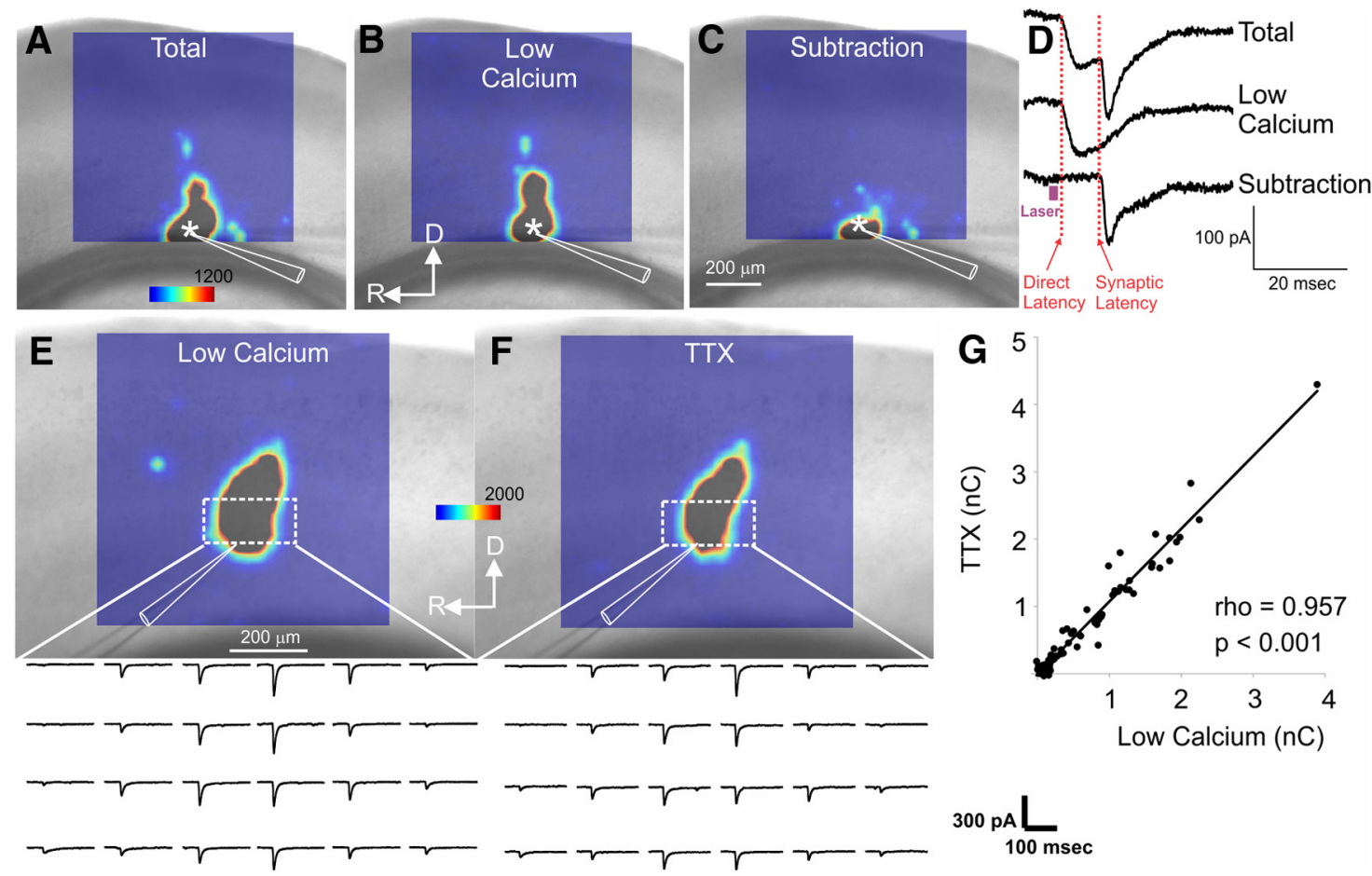

Figure 3. Low-calcium technique to separate direct versus synaptic inputs. $\boldsymbol{A}$, Total inward current map in a layer 6 corticocollicular neuron. $\boldsymbol{B}$, Same neuron, but here the map is shown using inward currents obtained using low-calcium aCSF. C, Subtraction map, obtained by subtracting the individual traces used to obtain the map shown in $\boldsymbol{B}$ from the current traces used to create the map shown in $\boldsymbol{A}$. D. Traces taken from the laser stimulation site denoted with an asterisk, demonstrating that this site contains a short-latency, multipeaked response, with the latter portion of the response being eliminated using a low-calcium aCSF solution, suggesting that this latter portion is synaptic in nature. $\boldsymbol{E}$, Direct inward current map of a layer 5 neuron obtained using low-calcium aCSF. Below the map is a series of current traces taken from the boxed area of the map. $F$, Direct inward current map of a layer 5 neuron obtained using TTX. Below the map is a series of current traces taken from the boxed area of the map. $G$, Correlation of the amplitude of responses of the direct inward current obtained using low-calcium aCSF (abscissa) and TTX (ordinate), measured at each stimulation site eliciting a response. Correlation coefficient (0.957) obtained using Spearman's correlation. Triangular outlined image corresponds to a diagram of the recording pipette, the tip of which points to the location of the recorded cell. Colorbars indicate $F$ statistic.

Qualitatively, the inward and outward current maps of layer 5 corticocollicular neurons differ substantially from those derived from layer 6 corticocollicular neurons because of the prominent excitatory and inhibitory input from layer $2 / 3$ onto layer 5 corticocollicular neurons. An analogous set of apical inputs is not seen in layer 6 corticocollicular neurons. This difference is reflected in the differences in the plots of synaptic input seen across the dorsoventral dimension (Fig. 5B, top row), which were compared using a two-sample Kolmogorov-Smirnov test, which revealed a highly significant difference in terms of the distribution of currents generated across stimulation sites ( $p=0.0001$ for excitation; $p=0.0001$ for inhibition). In contrast, no statistically significant differences were seen across the rostrocaudal axis $(p=$ 0.07 for excitation; $p=0.59$ for inhibition; Fig. $5 B$, bottom row). The vertical and horizontal spread of inputs was computed as FWHM around the recorded cells and was compared for inhibition versus excitation. The average horizontal FWHM for inhibition and excitation in layer 5 corticocollicular neurons was $156.1 \pm 67.7$ versus $157.9 \pm 169.3 \mu \mathrm{m}$, respectively (mean \pm SD; $p=0.18$, Mann-Whitney). The corresponding values for layer 6 corticocollicular neurons was $145.3 \pm 79.7$ versus $143.0 \pm 209.7$ $\mu \mathrm{m}$, respectively ( $p=0.16$, Mann-Whitney). The average vertical FWHM for inhibition and excitation in layer 5 corticocollicular neurons was $261.2 \pm 220.3$ versus $168.4 \pm 115.6 \mu \mathrm{m}$, respectively ( $p=0.52$, Mann-Whitney). The corresponding values for layer 6 corticocollicular neurons was $63.9 \pm 35.3$ versus $50.6 \pm 16.0 \mu \mathrm{m}$, respectively $(p=0.43$, Mann-Whitney). These data suggest that layer 5 and layer 6 corticocollicular neurons integrate synaptic inputs from different layers of cortex, but that they integrate from similar regions across the rostrocaudal axis, and that the distributions of excitatory and inhibitory inputs are similar.

To confirm that the differences seen in the dorsoventral dimension conform to different layers of cortex, synaptic inputs were pooled within layers, based on high-contrast images of the cortex to identify each layer (for example image, see Fig. 5C). Inputs from layers 1-3 were pooled and referred to as "supragranular (SG)." Direct comparison between inputs from any given layer also revealed significant differences between layers (Fig. 5D). For example, compared with layer 5 corticocollicular neurons, layer 6 corticocollicular neurons showed significantly more excitatory and inhibitory input from layer 6 ( $p=0.002$ and $p=0.0009$, respectively). In contrast, layer 5 corticocollicular neurons received greater excitatory and inhibitory input from all other cortical layers (layer 5 excitatory input: $p=0.01$; layer 5 inhibitory input: $p=0.002$; layer 4 excitatory input: $p=0.016$; layer 4 inhibitory input: $p=0.003$; SG excitatory input: $p=$ 0.041; SG inhibitory input: $p=0.024)$. These data suggest that layer 5 corticocollicular neurons vertically integrate excitatory and inhibitory inputs from the pia to layer 5, whereas layer 6 corticocollicular neurons integrate inputs primarily from layer 6 .

\section{Assessment of direct thalamic inputs to corticocollicular neurons}

Recent work has shown that neurons in both layer 5 and layer 6 receive direct input from the thalamus (Viaene et al., 2011; Constantinople and Bruno, 2013; Yang et al., 2014; Ji et al., 2016). The presence of a direct thalamic input to corticocollicular neurons 


\section{Excitation}
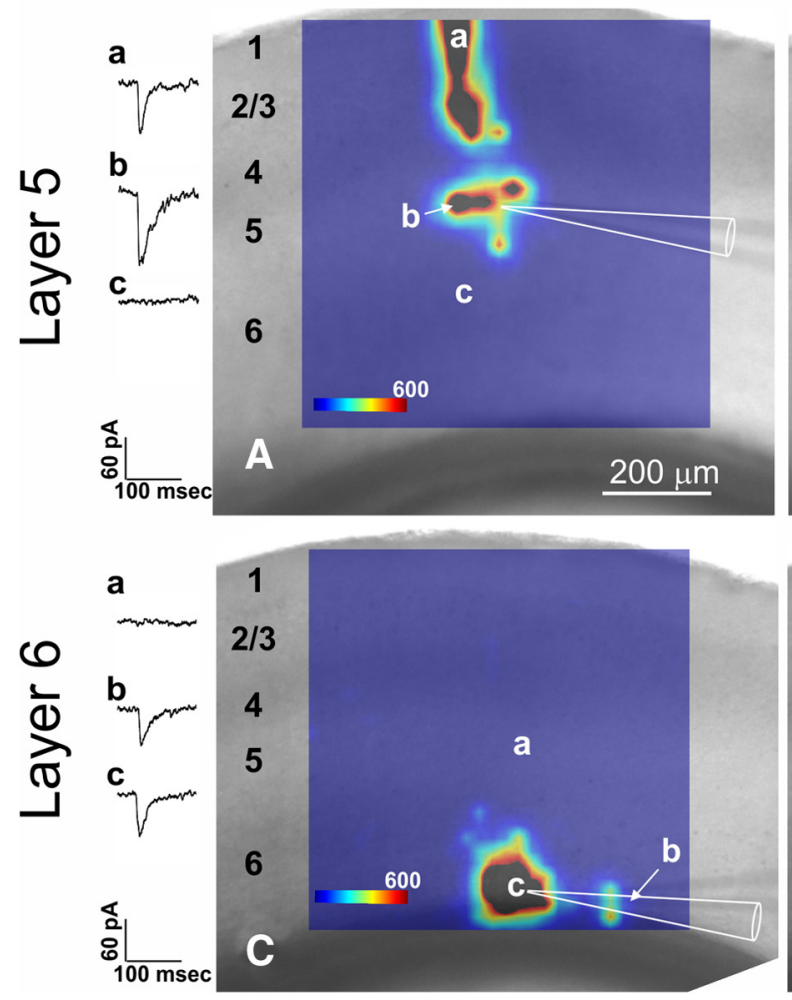

\section{Inhibition}
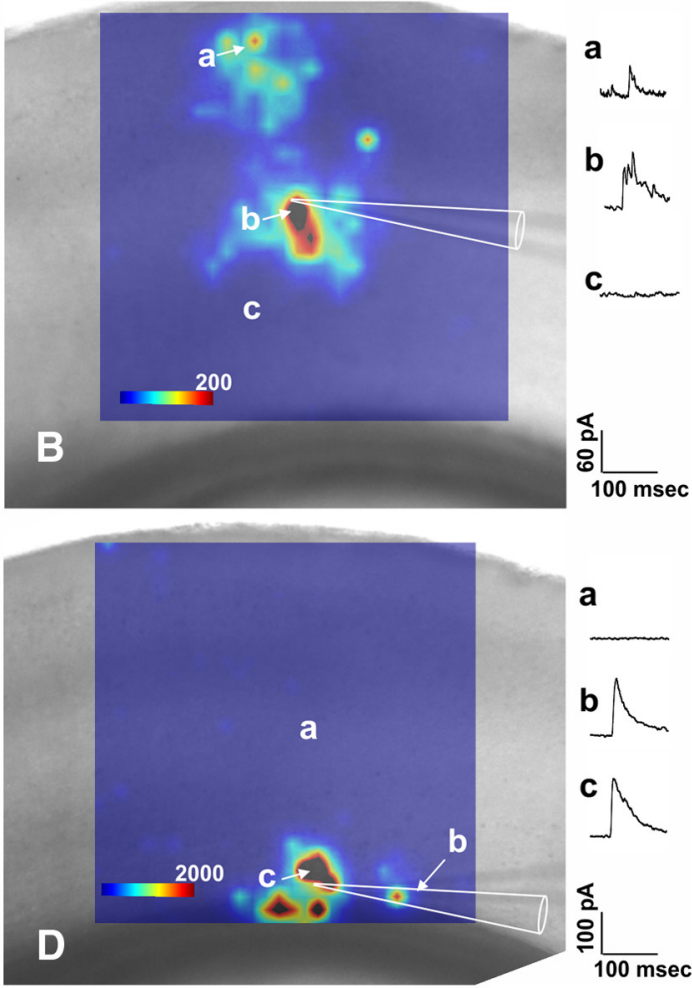

Figure 4. Example of synaptic input maps from matched layer 5 and layer 6 corticocollicular neurons. $A$, Excitatory synaptic input map from a layer 5 corticocollicular neuron. $\boldsymbol{B}$, Inhibitory synaptic input map from a layer 5 corticocollicular neuron. Excitatory $(\boldsymbol{C})$ and inhibitory $(\boldsymbol{D})$ synaptic input maps from a layer 6 corticocollicular neuron taken from just below the layer 5 neuron in $\boldsymbol{A}$ and $\boldsymbol{B}$. In all cases, traces from individual stimulation sites shown in a-c, which correspond to locations denoted on the adjacent heat maps. Colorbars indicate $F$ statistic.

would significantly impact models of corticofugal function because such an input would provide a short-latency mechanism to rapidly modulate ascending information. To determine whether layer 5 or layer 6 corticocollicular neurons received direct thalamic input, virally mediated expression of ChR-2 was used to label thalamocortical fibers. AAV-CaMKIIa-hChR2(H134R)mCherry virus (AAV2) was injected into the MGB to label the thalamic afferents (for a diagram of the double-injection animal preparation, see Fig. 6A). ChR-2 has been used previously in this manner to map long range projections (Petreanu et al., 2007, 2009; Cruikshank et al., 2010).

Thalamic input responses were recorded from retrogradely labeled corticocollicular neurons and were mapped in both layer 5 and 6 corticocollicular neurons $(n=5$ in each layer) using a $30 \times 30$ grid that covered much of the cortex as with the glutamate uncaging experiments. Both excitatory and inhibitory currents were measured. As previously noted in other studies of thalamocortical afferents (Cruikshank et al., 2010; Liu et al., 2011; Ji et al., 2016), inhibitory inputs were prominent. Inhibition was larger in layer 5 corticocollicular neurons compared with layer 6 corticocollicular neurons $(260 \pm 90 \mathrm{nC}$ vs $45.7 \pm 60$ $\mathrm{nC}, p=0.003$, Mann-Whitney $U$ test). Excitation was also larger in layer 5 corticocollicular neurons $(86.4 \pm 62 \mathrm{nC})$ compared with $19.2 \pm 15 \mathrm{nC}$ in layer 6 corticocollicular neurons $(p=0.02$, Mann-Whitney $U$ test; Fig. $6 B$ ). Layer 5 corticocollicular neurons received thalamic excitatory monosynaptic and disynaptic (or polysynaptic) input and disynaptic (or polysynaptic) inhibitory input from a broad region in layer 5 and extending to layer $2 / 3$ (for examples, see Fig. 6C1,C2). Layer 6 corticocollicular neurons received synaptic input from thalamocortical axons in layer
6. In addition, unlike the local synaptic input maps seen with caged glutamate, layer 6 corticocollicular neurons received an additional synaptic input from thalamocortical axons located at the border of layers 4 and 5 (for examples, see Fig. 6C3,C4).

From these data, it is apparent that both layers of interest receive substantial thalamic input. However, it is unclear from these experiments whether these thalamic inputs are monosynaptic or polysynaptic. Initially, to assess whether layer 5 and layer 6 corticocollicular neurons receive a monosynaptic thalamic input, the data generated from the mapping experiments were used to measure latency and jitter as indicators of a monosynaptic response (Doyle and Andresen, 2001; Karayannis et al., 2007). From the $30 \times 30$ grid of points used to stimulate thalamocortical afferents, a $3 \times 3$ subgrid of adjacent points around the cell was used to generate latency and jitter information from each of the neurons sampled. Latency was measured as the time between stimulation and $10 \%$ of the peak rise time of the current. Jitter was calculated as the SD of the latency.

It was found that both layer $5(n=5)$ and layer $6(n=5)$ corticocollicular neurons receive input from ChR-2-labeled fibers shortly after stimulation. Layer 5 corticocollicular neurons had shorter latencies with an average of $2.66 \pm 0.35$ ms versus layer 6 corticocollicular neurons, which had an average of $3.04 \pm$ $0.22 \mathrm{~ms}$ ( $n=5$ in each layer, $p=0.048$, Mann-Whitney $U$ test $)$. Similarly, the jitter of the response was smaller in layer 5 corticocollicular neurons $(0.31 \pm 0.22 \mathrm{~ms})$ compared with layer 6 corticocollicular neurons $(0.90 \pm 0.42 \mathrm{~ms}, n=5$ in each layer, $p=$ 0.017, Mann-Whitney $U$ test; see Fig. $7 A, B$ ).

Latencies and jitters were also measured for inhibitory responses, which are assumed to be at least disynaptic because 

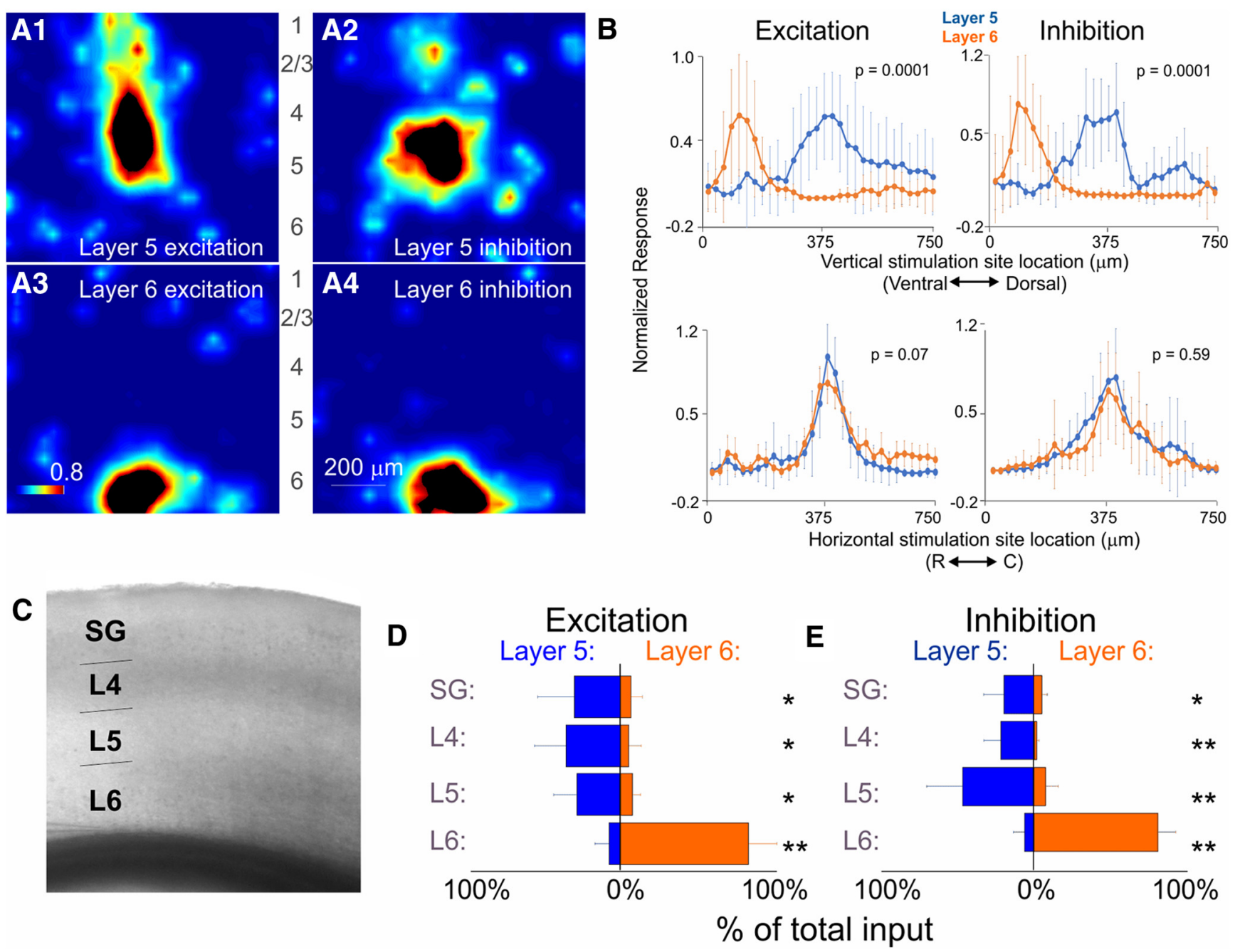

Figure 5. Summary of results comparing local excitation to layer 5 and layer 6 corticocollicular neurons. $\boldsymbol{A}$, Average of coregistered heatmaps for layer $5(\boldsymbol{A} \mathbf{1}, \boldsymbol{A} \mathbf{2})$ and layer $6(\boldsymbol{A} \mathbf{3}, \boldsymbol{A 4})$ corticocollicular neurons for both excitation (left) and inhibition (right). Colorbar indicates normalized Fstatistic. B, Average of the synaptic input, collapsed across all columns (top) or rows (bottom). In each case, the average synaptic input for each column or row is expressed as a normalized value relative to the maximum synaptic input to that neuron. Distance along abscissa corresponds to the 30 rows (top) or columns (bottom) of stimulation sites. $p$ values were generated using the Kolmogorov-Smirnov two-sample test. $C$, Representative raw image showing the delineation of the layers ( $L 4$, layer 4 ; L5, layer 5; $L 6$, layer 6 ) used for the analyses in $\boldsymbol{D}$ and $\boldsymbol{E} . \boldsymbol{D}, \boldsymbol{E}$, Two butterfly graphs comparing the mean excitatory $(\boldsymbol{D})$ and inhibitory $(\boldsymbol{E})$ input from individual layers to layer 5 and layer 6 corticocollicular neurons. ${ }^{*} p<0.05$ (Mann-Whitney $U$ test). ${ }^{* *} p<0.01$ (Mann-Whitney $U$ test). Error bars indicate SD.

thalamocortical terminals release glutamate and are therefore excitatory (Kharazia and Weinberg, 1994). Inhibitory latencies were significantly longer in layer 5 corticocollicular neurons at $4.77 \pm 1.20 \mathrm{~ms}$ compared with excitatory latencies, which were $2.66 \pm 0.35 \mathrm{~ms}(n=5, p=0.0079$, Mann-Whitney $U$ test $)$. Layer 5 also had larger jitter $(1.16 \pm 0.60 \mathrm{~ms})$ for inhibitory responses versus $0.31 \pm 0.22 \mathrm{~ms}$ for excitatory responses $(n=5, p=0.016$, Mann-Whitney $U$ test). Layer 6 corticocollicular neurons, similarly, showed a trend to have longer latencies for inhibitory responses $4.01 \pm 1.13 \mathrm{~ms}$, compared with excitatory responses $3.04 \pm 0.22 \mathrm{~ms}(n=5, p=0.095$, Mann-Whitney $U$ test $)$. There was a nonsignificant trend for the jitter in layer 6 corticocollicular neurons to be larger for inhibitory currents: $1.48 \pm 0.76 \mathrm{~ms}$ for inhibitory compared with $0.90 \pm 042 \mathrm{~ms}$ for excitatory currents $(n=5, p=0.18$, Mann-Whitney $U$ test; Fig. $7 A, B)$.

To unambiguously address whether layer 5 and layer 6 corticocollicular neurons receive monosynaptic inputs from the thalamus, in a subset of experiments, $2 \mu \mathrm{M}$ TTX was added to the circulating aCSF to block voltage-gated sodium channels. Activation of ChR-2 at the synapse will cause a release of neurotrans- mitter without requirement of the activation of voltage-gated sodium channels. Using TTX has been shown to limit polysynaptic propagation (Petreanu et al., 2009; Ji et al., 2016) by restricting input to only fibers in contact with a postsynaptic cell. The axonal potassium channel blocker 4-aminopyridine, which is often used to increase terminal release excitability in experiments involving TTX (Shu et al., 2007; Petreanu et al., 2009; Tritsch et al., 2012), was not necessary here given the strong laser-induced postsynaptic currents that were seen, likely due to the high release probability of the thalamocortical synapse (Gil et al., 1999).

Using this approach, it was found that optical stimulation of thalamocortical terminals produced EPSCs at least 3 SD above baseline noise calculated using the first $200 \mathrm{~ms}$ of the trace, suggesting direct synaptic contacts between these terminals and the recorded neurons. Layer 5 corticocollicular neurons receive direct input from the thalamus more often ( 11 of 11 cells) than layer 6 corticocollicular neurons ( 5 of 13 cells, $\chi^{2}=8.25, p=$ 0.004 ; for an example of a layer 5 corticocollicular neuron receiving direct thalamic input, see Fig. $7 C, D$ ). The introduction of TTX narrows the extent of input elicited with ChR-2 stimulation. 
A
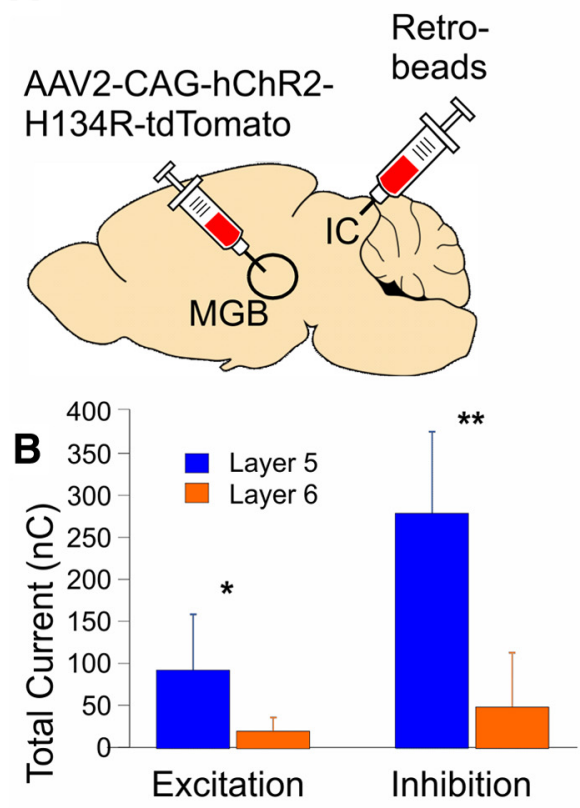

C1
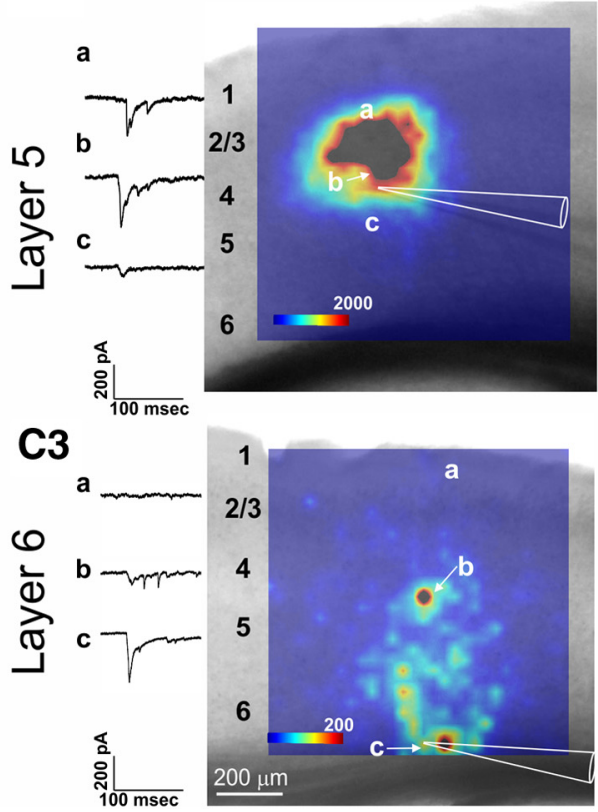

Excitation

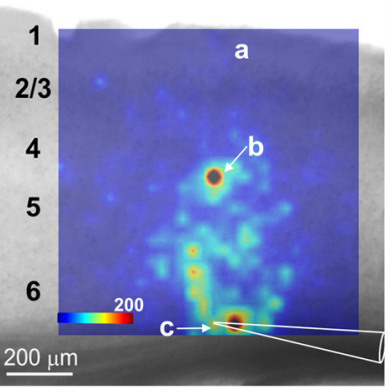

C2 Inhibition

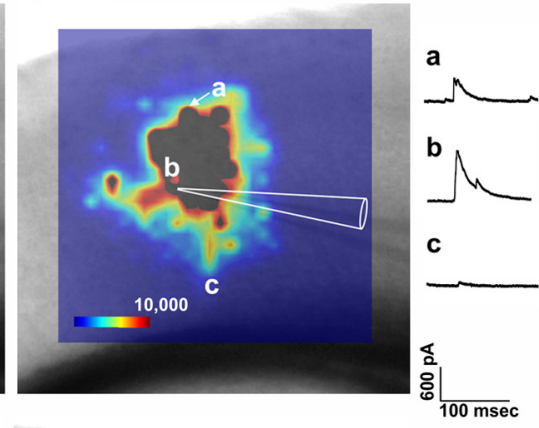

C4

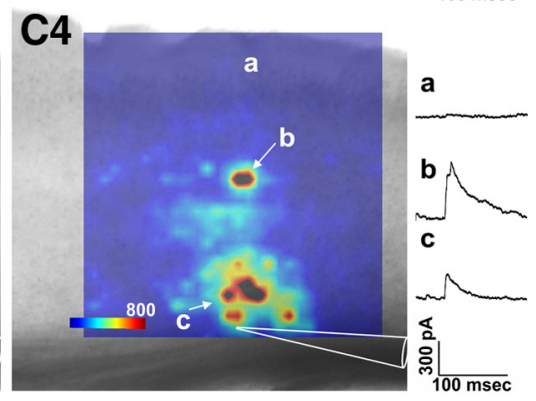

Figure 6. Mapping thalamic inputs to corticocollicular neurons. $A$, Schematic diagram illustrating the dual injections of an AAV virus expressing ChR- 2 in the MGB and red retro-beads into the IC. $\boldsymbol{B}$, Average excitatory and inhibitory current across all recorded cells $\left(n=5\right.$ per layer) elicited by stimulation of thalamocortical afferents. ${ }^{*} p<0.05$ (Mann-Whitney $U$ test). ${ }^{* *} p<0.01$ (Mann-Whitney U test). Error bars indicate SD. C1, Excitatory thalamic input map from a layer 5 corticocollicular neuron. C2, Inhibitory disynaptic (or polysynaptic) thalamic input map from a layer 5 corticocollicular neuron. C3, Excitatory thalamic input map from a layer 6 corticocollicular neuron. C4, Inhibitory disynaptic (or polysynaptic) thalamic input map from a layer 6 corticocollicular neuron. In all cases, traces from individual stimulation sites shown in a- $c$, which correspond to locations denoted on the adjacent heat maps. Colorbars indicate $F$ statistic.

A

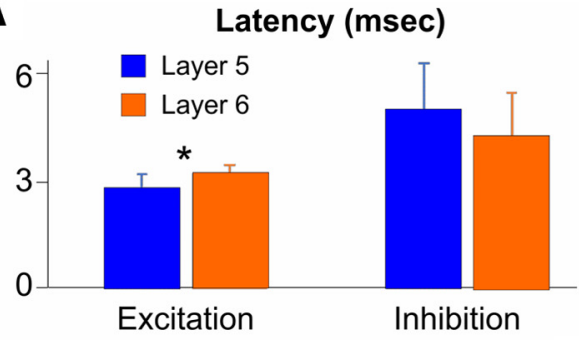

B

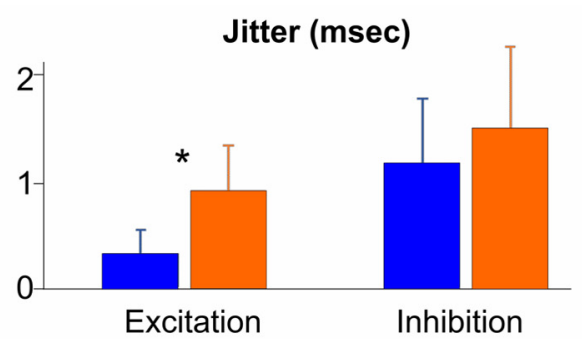

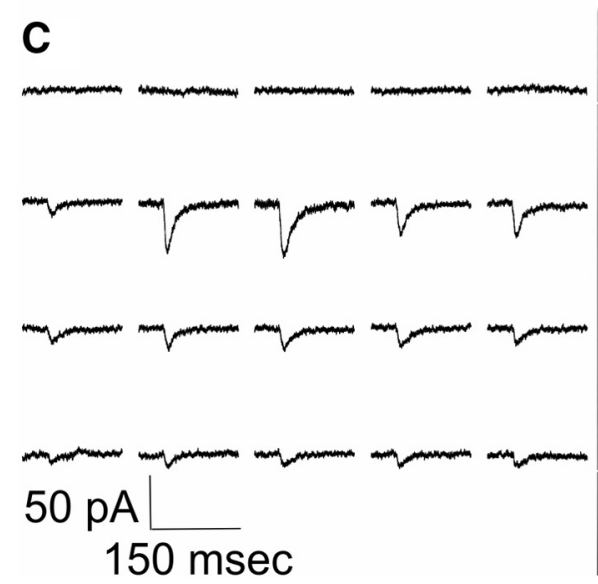

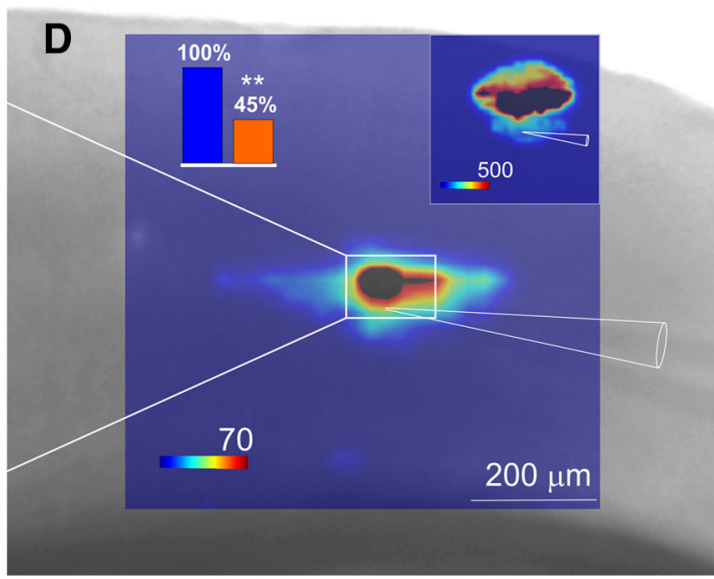

Figure 7. Direct inputs from the thalamus to corticocollicular neurons. $A$, Average latency from excitatory and inhibitory after stimulation of labeled thalamocortical axons to layer 5 and layer 6 corticocollicular neurons. $\boldsymbol{B}$, Average jitter from excitatory and inhibitory after stimulation of labeled thalamocortical axons to layer 5 and layer 6 corticocollicular neurons. ${ }^{*} p<0.05$ (Mann-Whitney $U$ test). Error bars indicate SD. C, Example traces from the boxed area in $\boldsymbol{D}$. $\boldsymbol{D}$, An example of an excitatory heat map in a layer 5 corticocollicular neuron obtained in $2 \mu \mathrm{m}$ TTX. Left inset, Percentage of layer 5 corticocollicular neurons ( 13 of 13 or 100\%) and layer 6 corticocollicular neurons ( 5 of 11 ) showing monosynaptic responses. ${ }^{* *} p<0.005$ ( $\chi^{2}$ test). Right inset, Pre-TTX map. Colorbars indicate F statistic. 


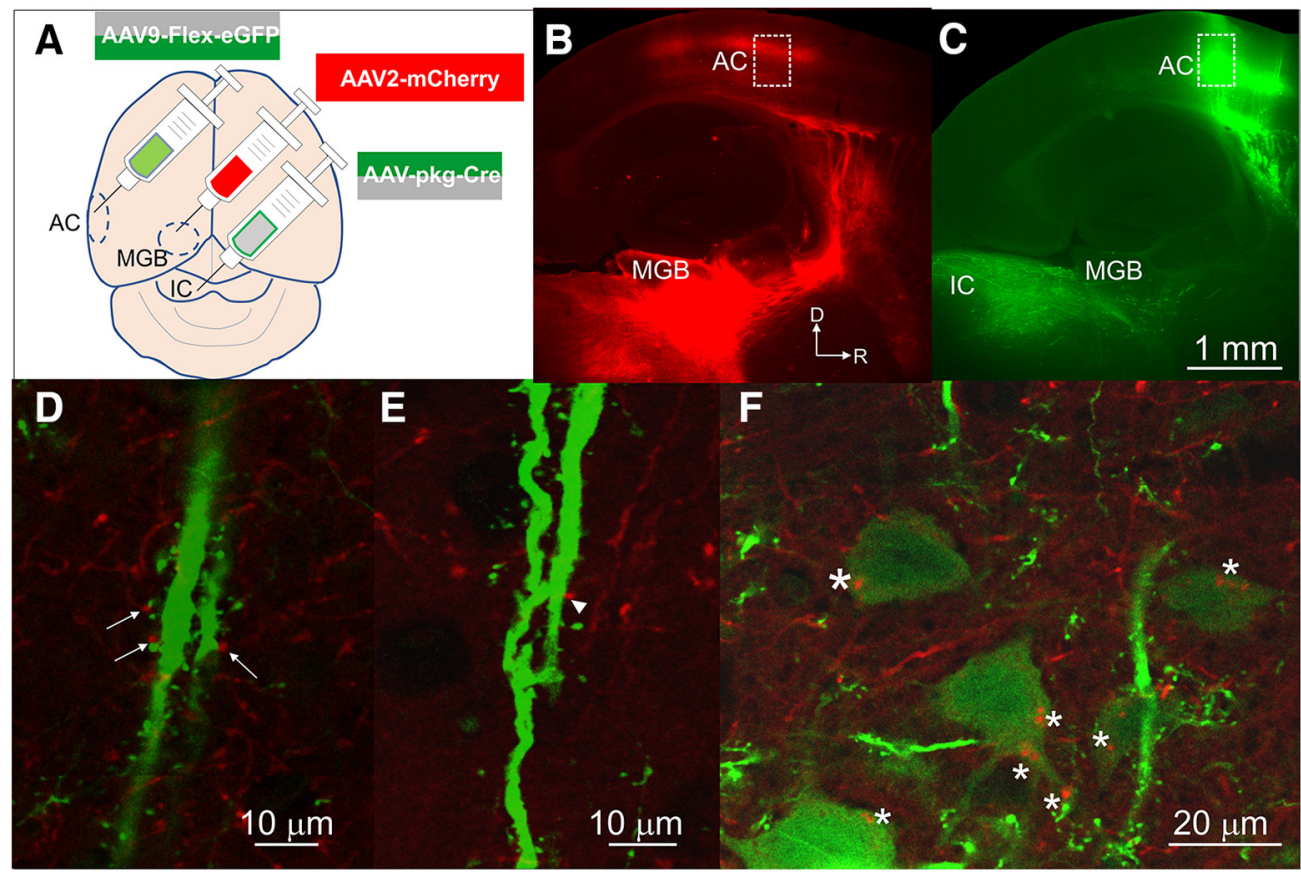

Figure 8. Localization of thalamic terminals and corticocollicular pyramidal neurons in layer 5 of the $A C$. $A$, Diagram of triple virus injection into the IC, MGB, and AC. The viruses injected into the IC and AC are complementary and require Cre-recombinase for GFP expression, hence the split color label. $\boldsymbol{B}$, Low-power micrograph showing the MGB injection site and anterogradely labeled fibers tracking to the AC. C, Low-power micrograph showing the GFP label, which includes labeled cells in the AC and associated descending projections to the IC. Dotted box corresponds to the areas analyzed in $\boldsymbol{D}-\boldsymbol{F}$. $\boldsymbol{D}-\boldsymbol{F}$, Images at high magnification showing putative thalamocortical contacts on dendritic spines ( $\boldsymbol{D}$, arrows), dendritic shafts ( $\boldsymbol{E}$, arrowhead), and cell bodies $(\boldsymbol{F}$, asterisks).

Therefore, it is likely that the total excitatory thalamic input (i.e., before adding TTX) to corticocollicular neurons is reflective of both the local cortical input driven by the thalamus as an ensemble and the direct thalamocortical input to a given corticocollicular neuron. This type of organization would indicate that the corticocollicular pathway is a nexus for direct thalamic and local cortical inputs.

To confirm and visualize thalamic inputs onto layer 5 corticocollicular neurons, two BALB/c mice were triple injected: (1) in the IC with a retrograde virus to induce Cre-recombinase expression in corticocollicular neurons; (2) in the primary AC with a Cre-dependent virus to visualize the back-labeled Cre-expressing neurons; and (3) into the MGB with a non-Cre-dependent anterograde virus to label thalamocortical terminals (Fig. $8 A$ ). In the AC, corticocollicular neurons expressing eGFP and thalamocortical terminals expressing mCherry were found (Fig. $8 \mathrm{~B}, \mathrm{C}$ ). Thalamocortical terminals were observed adjacent to dendritic spines (Fig. 8D, arrows), dendritic shafts (Fig. $8 E$, arrowhead), and somata (Fig. $8 F$, asterisks) of layer 5 corticocollicular neurons, suggesting the presence of multiple modes of thalamic modulation of these neurons. Similar findings were seen in a second animal (data not shown).

\section{Discussion}

\section{Summary}

In the current study, layer 5 and layer 6 corticocollicular neurons were found to receive distinct patterns of local cortical and thalamic input. Specifically, layer 5 corticocollicular neurons receive significantly more excitatory and inhibitory synaptic input from layer 5 and upper cortical layers, whereas layer 6 corticocollicular neurons receive a greater degree of corresponding input from layer 6 . In addition, while both layer 5 and layer 6 corticocollicular neurons receive thalamic input, it was determined that all recorded layer 5 corticocollicular neurons receive direct input from the MGB, whereas only a minority of layer 6 corticocollicular neurons receives direct thalamic input. The implications of these findings are discussed below.

\section{Technical considerations}

The time window method is commonly used to separate direct versus synaptic stimulation induced by uncaging glutamate (Jin et al., 2006; Hooks et al., 2013; Sturm et al., 2014; Meng et al., 2015). A practical point in favor of this technique is that it requires no extra caged glutamate, relying on only one uncaging map to yield results. However, others have shown that direct inputs to distal dendrites can fall outside of the window commonly used to separate direct and synaptic input, and that synaptic inputs close to the soma can fall within the window (Petreanu et al., 2009). Here, sites near the soma showed a mixture of direct and synaptic responses (Fig. 3D) that would normally be eliminated using the time-window technique. Validation using TTX shows close correspondence between the TTX and the low-calcium trace subtraction maps (Fig. $3 E-G$ ). The bias of the time window method to emphasize distal inputs may explain why excitatory input maps in this and previous work (Llano and Sherman, 2009) generally show less relative distal input onto recorded layer 5 neurons than previous studies (Schubert et al., 2001, 2006; Jacob et al., 2012).

\section{Neural circuits and functional implications}

Layer 5 and layer 6 corticocollicular neurons were found to be embedded in different local cortical circuits, which may influence how they modulate the IC. Layer 5 corticocollicular neurons share many properties with layer 5 corticothalamic neurons: (1) both populations comprise large pyramidal neurons with tufted thick apical dendrites; (2) both demonstrate intrinsic bursting firing patterns; (3) the current study suggests that both receive 
substantial excitatory and inhibitory input from layers 2-5 (Llano and Sherman, 2009); (4) both sets of neurons express the retinol binding protein-4 marker (Gerfen et al., 2013; Xiong et al., 2015); and (5) layer 5 auditory corticocollicular cells have been found to branch to thalamus and other subcortical structures (Moriizumi and Hattori, 1991; Doucet et al., 2003; Asokan et al., 2018). These data, combined with previous findings showing that nonauditory layer 5 corticofugal neurons branch widely to subcortical structures (Deschênes et al., 1994; Bourassa et al., 1995; Kita and Kita, 2012; Guo et al., 2017), suggest that layer 5 corticofugal neurons broadcast their signals across multiple levels of the sensory hierarchy. In contrast, the layer 6 corticocollicular neuronal morphological properties are unique within the cortex, having elongated and thin dendritic arborizations, in some cases reaching the pia and other cases extending into adjacent cortical columns (Slater et al., 2013). However, their excitatory synaptic inputs do not seem to differentiate them from other layer 6 neurons, such as the corticothalamic neurons (Llano and Sherman, 2009). This finding is somewhat surprising given their extensive dendritic arborizations, which in the current study do not appear to receive input from the upper layers of the cortex. It is possible that coordinated input is required to stimulate these layer 6 neurons, as groups of neurons are often activated in ensembles, particularly from thalamic inputs (Bruno and Sakmann, 2006; Wang et al., 2010). This supposition is supported by the current finding that optogenetic stimulation, which activates populations of afferent fibers, is better able to drive layer 6 corticocollicular neurons from distal sites than glutamate stimulation (e.g., compare Fig. $6 C 3, C 4$ with Fig. $4 C, D$ ). This finding is also consistent with the notion that coordinated activity across an auditory cortical column is required to permit activation of individual cells in that column (Sakata and Harris, 2009; Krause et al., 2014). As such, it is possible that focal glutamate stimulation, in isolation, is unable to activate the thin dendrites found in the layer 6 corticocollicular neurons in such a way that the activation is reflected in a somatic current.

Horizontal integration of excitation and inhibition in both sets of neurons resulted in an FWHM of 100-200 $\mu \mathrm{m}$. This width is approximately similar to what has been seen in previous studies of other cell types of the mouse AC in both coronal and horizontal orientations (Llano and Sherman, 2009; Oviedo et al., 2010; Watkins et al., 2014; Kratz and Manis, 2015; Meng et al., 2015; Oviedo, 2017). Although the width of an auditory cortical column in the mouse has not yet been defined, the similarity of widths seen across studies, as well as to anatomically defined columns in the vibrissal system (100-200 $\mu \mathrm{m})$ (Simons and Woolsey, 1979; Watson et al., 2006), suggest that the bulk of inputs seen with laser photostimulation conform to that of a functional column.

The presence of layer 6 auditory corticollicular projections has been reported in mice, rats, gerbils, ferrets, and hedgehog tenrec (Games and Winer, 1988; Künzle, 1995; Doucet et al., 2003; Bajo and Moore, 2005; Bajo et al., 2007; Schofield, 2009; Slater et al., 2013), but not in two studies in the cat: one using HRP as a tracer (Kelly and Wong, 1981) and the other using wheat-germ agglutinin-HRP (Winer and Prieto, 2001). The current study suggests that layer 6 corticocollicular neurons comprise a substantial minority $(25 \%)$ of the total projection in mouse, which appears higher than the two previous studies that have reported the distribution (rat and guinea pig, $\sim 10 \%$ ) (Games and Winer, 1988; Schofield, 2009). It is not yet known whether the differences here are related to species or tracer-related differences, although it is noted that the tracer used here (Fluoro-Gold) is considerably more sensitive than previous generations of tracers (Schofield, 2008). It is possible that the high proportion reported in mouse is species-specific, and therefore not generalizable. However, given the current heavy use of mice to understand the auditory system, it will be important to differentiate the layer 6 from the layer 5 contribution to modulation of the IC to fully understand the functional organization of the corticocollicular system in these model animals. Although the specific role of layer 6 corticocollicular projections is not yet known, it is possible that they play a role in cortical development or provide arousal-dependent modulation of the IC, given their proximity to persistent subplate neurons and orexin-2 staining neurons, respectively (Bayer et al., 2004; Kanold, 2009). Future work will clarify these issues.

\section{Thalamic connections to corticocollicular neurons}

The findings in the current study that demonstrate direct connectivity between the thalamus and corticocollicular neurons are consistent with a growing body of literature that demonstrates thalamic inputs to neurons whose somata lie in layers outside layer 4 (Huang and Winer, 2000; Cruikshank et al., 2010; Smith et al., 2012; Constantinople and Bruno, 2013; Krause et al., 2014; Ji et al., 2016). For example, a previous study in the somatosensory cortex found that preidentified layer 6 corticothalamic neurons receive direct thalamic input (Yang et al., 2014). The investigators used electrical stimulation of thalamocortical afferents and found similar average latencies $(2.52 \mathrm{~ms})$ and jitter $(0.17 \mathrm{~ms})$ to our findings in layer 5 , where the average latency $=2.66 \mathrm{~ms}$ and average jitter $=0.35 \mathrm{~ms}$. The work presented here is the first evidence in the auditory system that there is a direct connection between the ascending projections and the descending projections, and the use of ChR-2 allowed for the definitive determination of monosynaptic thalamocortical input to corticocollicular neurons.

Combining the current data with previous work demonstrating differences in firing properties of layer 5 and layer 6 corticocollicular neurons (Slater et al., 2013), and work demonstrating that auditory corticocollicular neurons target the matrix portion of the lateral cortex of the IC while somatosensory inputs target GABAergic modules (Lesicko et al., 2016), we propose that layer 5 neurons receive short-latency thalamocortical input along with upper layer local cortical input, to rapidly send bursts of action potentials to the ipsilateral and contralateral matrix portions of the IC. Layer 6 corticocollicular neurons are less likely to get direct thalamic input but may respond to population thalamic activity, modulated by local inputs, to send trains of individual action potentials to neurons in the IC. Given the numerous potential functions that have been hypothesized for the corticocollicular pathway (Zhang et al., 1997; Yan et al., 2005; Suga, 2008; Bajo et al., 2010; Xiong et al., 2015; Robinson et al., 2016), such a duplex system may be necessary to instantiate modulation that may require different time scales, different degrees of convergence or divergence, and different degrees of inhibition and excitation. Future work will elucidate the specifics of how these two pathways modulate the IC.

\section{References}

Abercrombie M (1946) Estimation of nuclear population from microtome sections. Anat Rec 94:239-247. CrossRef Medline

Andersen RA, Snyder RL, Merzenich MM (1980) The topographic organization of corticocollicular projections from physiologically identified loci in the AI, AII, and anterior auditory cortical fields of the cat. J Comp Neurol 191:479-494. CrossRef Medline

Asokan MM, Williamson RS, Hancock KE, Polley DB (2018) Sensory over- 
amplification in layer 5 auditory corticofugal projection neurons following cochlear nerve synaptic damage. Nat Commun 9:2468. CrossRef Medline

Assimakopoulos PA, Boyd DP, Jaschke W, Lipton MJ (1986) Spatial resolution analysis of computed tomographic images. Invest Radiol 21:260271. CrossRef Medline

Bajo VM, King AJ (2012) Cortical modulation of auditory processing in the midbrain. Front Neural Circuits 6:114. CrossRef Medline

Bajo VM, Moore DR (2005) Descending projections from the auditory cortex to the inferior colliculus in the gerbil, Meriones unguiculatus. J Comp Neurol 486:101-116. CrossRef Medline

Bajo VM, Nodal FR, Bizley JK, Moore DR, King AJ (2007) The ferret auditory cortex: descending projections to the inferior colliculus. Cereb Cortex 17:475-491. CrossRef Medline

Bajo VM, Nodal FR, Moore DR, King AJ (2010) The descending corticocollicular pathway mediates learning-induced auditory plasticity. Nat Neurosci 13:253-260. CrossRef Medline

Bayer L, Serafin M, Eggermann E, Saint-Mleux B, Machard D, Jones BE, Mühlethaler M (2004) Exclusive postsynaptic action of hypocretinorexin on sublayer 6b cortical neurons. J Neurosci 24:6760-6764. CrossRef Medline

Bourassa J, Pinault D, Deschênes M (1995) Corticothalamic projections from the cortical barrel field to the somatosensory thalamus in rats: a single-fibre study using biocytin as an anterograde tracer. Eur J Neurosci 7:19-30. CrossRef Medline

Bowman FD (2014) Brain imaging analysis. Annu Rev Stat Application 1:61-85. CrossRef

Bruno RM, Sakmann B (2006) Cortex is driven by weak but synchronously active thalamocortical synapses. Science 312:1622-1627. CrossRef Medline

Budinger E, Heil P, Scheich H (2000a) Functional organization of auditory cortex in the mongolian gerbil (Meriones unguiculatus): IV. Connections with anatomically characterized subcortical structures. Eur J Neurosci 12:2452-2474. CrossRef Medline

Budinger E, Heil P, Scheich H (2000b) Functional organization of auditory cortex in the mongolian gerbil (Meriones unguiculatus): III. Anatomical subdivisions and corticocortical connections. Eur J Neurosci 12:24252451. CrossRef Medline

Callaway EM, Katz LC (1993) Photostimulation using caged glutamate reveals functional circuitry in living brain slices. Proc Natl Acad Sci U S A 90:7661-7665. CrossRef Medline

Constantinople CM, Bruno RM (2013) Deep cortical layers are activated directly by thalamus. Science 340:1591-1594. CrossRef Medline

Coomes DL, Schofield RM, Schofield BR (2005) Unilateral and bilateral projections from cortical cells to the inferior colliculus in guinea pigs. Brain Res 1042:62-72. CrossRef Medline

Cruikshank SJ, Rose HJ, Metherate R (2002) Auditory thalamocortical synaptic transmission in vitro. J Neurophysiol 87:361-384. CrossRef Medline

Cruikshank SJ, Urabe H, Nurmikko AV, Connors BW (2010) Pathwayspecific feedforward circuits between thalamus and neocortex revealed by selective optical stimulation of axons. Neuron 65:230-245. CrossRef Medline

Deschênes M, Bourassa J, Pinault D (1994) Corticothalamic projections from layer $\mathrm{V}$ cells in rat are collaterals of long-range corticofugal axons. Brain Res 664:215-219. CrossRef Medline

Doucet JR, Molavi DL, Ryugo DK (2003) The source of corticocollicular and corticobulbar projections in area Tel of the rat. Exp Brain Res 153: 461-466. CrossRef Medline

Doyle MW, Andresen MC (2001) Reliability of monosynaptic sensory transmission in brain stem neurons in vitro. J Neurophysiol 85:22132223. CrossRef Medline

Druga R, Syka J, Rajkowska G (1997) Projections of auditory cortex onto the inferior colliculus in the rat. Physiol Res 46:215-222. Medline

Franklin K, Paxinos G (2007) The mouse brain in stereotaxic coordinates, Ed 3. Amsterdam: Elsevier.

Friston KJ (1998) Imaging neuroscience: principles or maps? Proc Natl Acad Sci U S A 95:796-802. CrossRef Medline

Games KD, Winer JA (1988) Layer V in rat auditory cortex: projections to the inferior colliculus and contralateral cortex. Hear Res 34:1-25. CrossRef Medline

Gao E, Suga N (2000) Experience-dependent plasticity in the auditory cortex and the inferior colliculus of bats: role of the corticofugal system. Proc Natl Acad Sci U S A 97:8081-8086. CrossRef Medline
Gerfen CR, Paletzki R, Heintz N (2013) GENSAT BAC cre-recombinase driver lines to study the functional organization of cerebral cortical and basal ganglia circuits. Neuron 80:1368-1383. CrossRef Medline

Gil Z, Connors BW, Amitai Y (1999) Efficacy of thalamocortical and intracortical synaptic connections: quanta, innervation, and reliability. Neuron 23:385-397. CrossRef Medline

Gramfort A, Peyré G, Cuturi M (2015) Fast optimal transport averaging of neuroimaging data. In: International Conference on Information Processing in Medical Imaging, pp 261-272. New York: Springer.

Guo C, Peng J, Zhang Y, Li A, Li Y, Yuan J, Xu X, Ren M, Gong H, Chen S (2017) Single-axon level morphological analysis of corticofugal projection neurons in mouse barrel field. Sci Rep 7:2846. CrossRef Medline

Harris JA, Wook Oh S, Zeng H (2012) Adeno-associated viral vectors for anterograde axonal tracing with fluorescent proteins in nontransgenic and cre driver mice. Curr Protoc Neurosci 20:1-18. CrossRef Medline

Holm S (1979) A simple sequentially rejective multiple test procedure. Scand J Stat 6:65-70.

Hooks BM, Mao T, Gutnisky DA, Yamawaki N, Svoboda K, Shepherd GM (2013) Organization of cortical and thalamic input to pyramidal neurons in mouse motor cortex. J Neurosci 33:748-760. CrossRef Medline

Howseman AM, Josephs O, Rees G, Friston KJ (1997) Special issues in functional magnetic resonance imaging. In Human Brain Function (Frackowiak R, Frith C, Friston K, Dolan R, Mazziotta J, Turner R, eds). London: Academic Press.

Huang CL, Winer JA (2000) Auditory thalamocortical projections in the cat: laminar and areal patterns of input. J Comp Neurol 427:302-331. CrossRef Medline

Jacob V, Petreanu L, Wright N, Svoboda K, Fox K (2012) Regular spiking and intrinsic bursting pyramidal cells show orthogonal forms of experience-dependent plasticity in layer $\mathrm{V}$ of barrel cortex. Neuron 73 : 391-404. CrossRef Medline

Ji XY, Zingg B, Mesik L, Xiao Z, Zhang LI, Tao HW (2016) Thalamocortical innervation pattern in mouse auditory and visual cortex: laminar and cell-type specificity. Cereb Cortex 26:2612-2625. CrossRef Medline

Jin X, Prince DA, Huguenard JR (2006) Enhanced excitatory synaptic connectivity in layer $\mathrm{V}$ pyramidal neurons of chronically injured epileptogenic neocortex in rats. J Neurosci 26:4891-4900. CrossRef Medline

Kanold PO (2009) Subplate neurons: crucial regulators of cortical development and plasticity. Front Neuroanat 3:16. CrossRef Medline

Karayannis T, Huerta-Ocampo I, Capogna M (2007) GABAergic and pyramidal neurons of deep cortical layers directly receive and differently integrate callosal input. Cereb Cortex 17:1213-1226. CrossRef Medline

Kelly JP, Wong D (1981) Laminar connections of the cat's auditory cortex. Brain Res 212:1-15. CrossRef Medline

Kharazia VN, Weinberg RJ (1994) Glutamate in thalamic fibers terminating in layer IV of primary sensory cortex. J Neurosci 14:6021-6032. CrossRef Medline

Kita T, Kita H (2012) The subthalamic nucleus is one of multiple innervation sites for long-range corticofugal axons: a single-axon tracing study in the rat. J Neurosci 32:5990-5999. CrossRef Medline

Kratz MB, Manis PB (2015) Spatial organization of excitatory synaptic inputs to layer 4 neurons in mouse primary auditory cortex. Front Neural Circuits 9:17. CrossRef Medline

Krause BM, Raz A, Uhlrich DJ, Smith PH, Banks MI (2014) Spiking in auditory cortex following thalamic stimulation is dominated by cortical network activity. Front Syst Neurosci 8:170. CrossRef Medline

Künzle H (1995) Regional and laminar distribution of cortical neurons projecting to either superior or inferior colliculus in the hedgehog tenrec. Cereb Cortex 5:338-352. CrossRef Medline

Lesicko AM, Hristova TS, Maigler KC, Llano DA (2016) Connectional modularity of top-down and bottom-up multimodal inputs to the lateral cortex of the inferior colliculus. J Neurosci 36:11037-11050. CrossRef Medline

Liu BH, Li YT, Ma WP, Pan CJ, Zhang LI, Tao HW (2011) Broad inhibition sharpens orientation selectivity by expanding input dynamic range in mouse simple cells. Neuron 71:542-554. CrossRef Medline

Llano DA, Sherman SM (2009) Differences in intrinsic properties and local network connectivity of identified layer 5 and layer 6 adult mouse auditory corticothalamic neurons support a dual corticothalamic projection hypothesis. Cereb Cortex 19:2810-2826. CrossRef Medline

Llano DA, Slater BJ, Lesicko AM, Stebbings KA (2014) An auditory collicu- 
lothalamocortical brain slice preparation in mouse. J Neurophysiol 111: 197-207. CrossRef Medline

Ma X, Suga N (2001) Corticofugal modulation of duration-tuned neurons in the midbrain auditory nucleus in bats. Proc Natl Acad Sci U S A 98: 14060-14065. CrossRef Medline

Markram H, Helm PJ, Sakmann B (1995) Dendritic calcium transients evoked by single back-propagating action potentials in rat neocortical pyramidal neurons. J Physiol 485:1-20. CrossRef Medline

Meng X, Kao JP, Lee HK, Kanold PO (2015) Visual deprivation causes refinement of intracortical circuits in the auditory cortex. Cell Rep 12:955964. CrossRef Medline

Mitani A, Shimokouchi M, Nomura S (1983) Effects of stimulation of the primary auditory cortex upon colliculogeniculate neurons in the inferior colliculus of the cat. Neurosci Lett 42:185-189. CrossRef Medline

Moriizumi T, Hattori T (1991) Pyramidal cells in rat temporoauditory cortex project to both striatum and inferior colliculus. Brain Res Bull 27:141144. CrossRef Medline

Nakamoto KT, Jones SJ, Palmer AR (2008) Descending projections from auditory cortex modulate sensitivity in the midbrain to cues for spatial position. J Neurophysiol 99:2347-2356. CrossRef Medline

Nakamoto KT, Shackleton TM, Palmer AR (2010) Responses in the inferior colliculus of the guinea pig to concurrent harmonic series and the effect of inactivation of descending controls. J Neurophysiol 103:2050-2061. CrossRef Medline

Ojima H (1994) Terminal morphology and distribution of corticothalamic fibers originating from layers 5 and 6 of cat primary auditory cortex. Cereb Cortex 4:646-663. CrossRef Medline

Oviedo HV (2017) Connectivity motifs of inhibitory neurons in the mouse auditory cortex. Sci Rep 7:16987. CrossRef Medline

Oviedo HV, Bureau I, Svoboda K, Zador AM (2010) The functional asymmetry of auditory cortex is reflected in the organization of local cortical circuits. Nat Neurosci 13:1413-1420. CrossRef Medline

Penny WD, Friston KJ, Ashburner JT, Kiebel SJ, Nichols TE (2011) Statistical parametric mapping: the analysis of functional brain images. San Diego: Academic.

Petreanu L, Huber D, Sobczyk A, Svoboda K (2007) Channelrhodopsin-2assisted circuit mapping of long-range callosal projections. Nat Neurosci 10:663-668. CrossRef Medline

Petreanu L, Mao T, Sternson SM, Svoboda K (2009) The subcellular organization of neocortical excitatory connections. Nature 457:1142-1145. CrossRef Medline

Petrof I, Viaene AN, Sherman SM (2015) Properties of the primary somatosensory cortex projection to the primary motor cortex in the mouse. J Neurophysiol 113:2400-2407. CrossRef Medline

Reichova I, Sherman SM (2004) Somatosensory corticothalamic projections: distinguishing drivers from modulators. J Neurophysiol 92:21852197. CrossRef Medline

Robinson BL, Harper NS, McAlpine D (2016) Meta-adaptation in the auditory midbrain under cortical influence. Nat Commun 7:13442. CrossRef Medline

Rock C, Apicella AJ (2015) Callosal projections drive neuronal-specific responses in the mouse auditory cortex. J Neurosci 35:6703-6713. CrossRef Medline

Sakata S, Harris KD (2009) Laminar structure of spontaneous and sensoryevoked population activity in auditory cortex. Neuron 64:404-418. CrossRef Medline

Schofield BR (2008) Retrograde axonal tracing with fluorescent markers. Curr Protoc Neurosci 1:17. CrossRef Medline

Schofield BR (2009) Projections to the inferior colliculus from layer VI cells of auditory cortex. Neuroscience 159:246-258. CrossRef Medline

Schofield BR, Motts SD (2009) Projections from auditory cortex to cholinergic cells in the midbrain tegmentum of guinea pigs. Brain Res Bull 80:163-170. CrossRef Medline

Schubert D, Staiger JF, Cho N, Kötter R, Zilles K, Luhmann HJ (2001) Layer-specific intracolumnar and transcolumnar functional connectivity of layer V pyramidal cells in rat barrel cortex. J Neurosci 21:3580-3592. CrossRef Medline

Schubert D, Kötter R, Luhmann HJ, Staiger JF (2006) Morphology, electrophysiology and functional input connectivity of pyramidal neurons characterizes a genuine layer Va in the primary somatosensory cortex. Cereb Cortex 16:223-236. CrossRef Medline
Shepherd GM (2012) Circuit mapping by ultraviolet uncaging of glutamate. Cold Spring Harb Protoc 20:998-1004. CrossRef Medline

Shu Y, Yu Y, Yang J, McCormick DA (2007) Selective control of cortical axonal spikes by a slowly inactivating $\mathrm{K}^{+}$current. Proc Natl Acad Sci U S A 104:11453-11458. CrossRef Medline

Simons DJ, Woolsey TA (1979) Functional organization in mouse barrel cortex. Brain Res 165:327-332. CrossRef Medline

Slater BJ, Willis AM, Llano DA (2013) Evidence for layer-specific differences in auditory corticocollicular neurons. Neuroscience 229:144-154. CrossRef Medline

Slater BJ, Fan A, Stebbings KA, Saif T, Llano DA (2015) Modification of a colliculo-thalamocortical mouse brain slice, incorporating 3D printing of chamber components and multi-scale optical imaging. J Vis Exp 18:103. CrossRef Medline

Smith PH, Uhlrich DJ, Manning KA, Banks MI (2012) Thalamocortical projections to rat auditory cortex from the ventral and dorsal divisions of the medial geniculate nucleus. J Comp Neurol 520:34-51. CrossRef Medline

Staiger JF, Kötter R, Zilles K, Luhmann HJ (1999) Connectivity in the somatosensory cortex of the adolescent rat: an in vitro biocytin study. Anat Embryol 199:357-365. CrossRef Medline

Stebbings KA, Lesicko AM, Llano DA (2014) The auditory corticocollicular system: molecular and circuit-level considerations. Hear Res 314:51-59. CrossRef Medline

Sturm JJ, Zhang-Hooks YX, Roos H, Nguyen T, Kandler K (2017) Noise trauma-induced behavioral gap detection deficits correlate with reorganization of excitatory and inhibitory local circuits in the inferior colliculus and are prevented by acoustic enrichment. J Neurosci 37:6314-6330. CrossRef Medline

Sturm J, Nguyen T, Kandler K (2014) Development of intrinsic connectivity in the central nucleus of the mouse inferior colliculus. J Neurosci 34: 15032-15046. CrossRef Medline

Suga N (2008) Role of corticofugal feedback in hearing. J Comp Physiol A Neuroethol Sens Neural Behav Physiol 194:169-183. CrossRef Medline

Theyel BB, Llano DA, Sherman SM (2010) The corticothalamocortical circuit drives higher-order cortex in the mouse. Nat Neurosci 13:84-88. CrossRef Medline

Thomson AM, West DC, Wang Y, Bannister AP (2002) Synaptic connections and small circuits involving excitatory and inhibitory neurons in layers $2-5$ of adult rat and cat neocortex: triple intracellular recordings and biocytin labelling in vitro. Cereb Cortex 12:936-953. CrossRef Medline

Tritsch NX, Ding JB, Sabatini BL (2012) Dopaminergic neurons inhibit striatal output through non-canonical release of GABA. Nature 490:262-266. CrossRef Medline

Viaene AN, Petrof I, Sherman SM (2011) Synaptic properties of thalamic input to layers $2 / 3$ and 4 of primary somatosensory and auditory cortices. J Neurophysiol 105:279-292. CrossRef Medline

Wang HP, Spencer D, Fellous JM, Sejnowski TJ (2010) Synchrony of thalamocortical inputs maximizes cortical reliability. Science 328:106109. CrossRef Medline

Watkins PV, Kao JP, Kanold PO (2014) Spatial pattern of intra-laminar connectivity in supragranular mouse auditory cortex. Front Neural Circuits 8:15. CrossRef Medline

Watson RF, Abdel-Majid RM, Barnett MW, Willis BS, Katsnelson A, Gillingwater TH, McKnight GS, Kind PC, Neumann PE (2006) Involvement of protein kinase A in patterning of the mouse somatosensory cortex. J Neurosci 26:5393-5401. CrossRef Medline

Winer JA (2006) Decoding the auditory corticofugal systems. Hear Res 212: 1-8. CrossRef Medline

Winer JA, Prieto JJ (2001) Layer V in cat primary auditory cortex (AI): cellular architecture and identification of projection neurons. J Comp Neurol 434:379-412. CrossRef Medline

Worsley KJ, Liao CH, Aston J, Petre V, Duncan GH, Morales F, Evans AC (2002) A general statistical analysis for fMRI data. Neuroimage 15:1-15. CrossRef Medline

Xiong XR, Liang F, Zingg B, Ji XY, Ibrahim LA, Tao HW, Zhang LI (2015) Auditory cortex controls sound-driven innate defense behaviour through corticofugal projections to inferior colliculus. Nat Commun 6:7224. CrossRef Medline

Yan J, Ehret G (2001) Corticofugal reorganization of the midbrain tonotopic map in mice. Neuroreport 12:3313-3316. CrossRef Medline 
Yan J, Zhang Y, Ehret G (2005) Corticofugal shaping of frequency tuning curves in the central nucleus of the inferior colliculus of mice. J Neurophysiol 93:71-83. CrossRef Medline

Yang Q, Chen CC, Ramos RL, Katz E, Keller A, Brumberg JC (2014) Intrinsic properties of and thalamocortical inputs onto identified corticothalamic-VPM neurons. Somatosens Mot Res 31:78-93. CrossRef Medline

Zarrinpar A, Callaway EM (2006) Local connections to specific types of layer 6 neurons in the rat visual cortex. J Neurophysiol 95:1751-1761. CrossRef Medline

Zarrinpar A, Callaway EM (2016) Functional local input to layer 5 pyramidal neurons in the rat visual cortex. Cereb Cortex 26:991-1003. CrossRef Medline

Zhang F, Aravanis AM, Adamantidis A, de Lecea L, Deisseroth K (2007)
Circuit-breakers: optical technologies for probing neural signals and systems. Nat Rev Neurosci 8:577-581. CrossRef Medline

Zhang Y, Suga N, Yan J (1997) Corticofugal modulation of frequency processing in bat auditory system. Nature 387:900-903. CrossRef Medline

Zhao C, Kao JP, Kanold PO (2009) Functional excitatory microcircuits in neonatal cortex connect thalamus and layer 4. J Neurosci 29:1547915488. CrossRef Medline

Zheng QY, Johnson KR, Erway LC (1999) Assessment of hearing in 80 inbred strains of mice by ABR threshold analyses. Hear Res 130:94-107. CrossRef Medline

Zurita H, Rock C, Perkins J, Apicella AJ (2018) A layer-specific corticofugal input to the mouse superior colliculus. Cereb Cortex 28:281-2833. CrossRef Medline 